\title{
PRESENCIA Y ACTIVIDAD DE LOS BURGUESES EN LAS SOCIEDADES ECONÓMICAS
}

Luis Miguel ENCISO RECIO

Desde la lejana reunión de San Sebastián, en 1972, hasta el reciente Congreso de Chiavari (1988), donde se dieron cita múltiples especialistas europeos, la historiografía sobre las Sociedades Económicas ha crecido en volumen y rigor metodológico. A lo largo de este prolongado paréntesis de tiempo los investigadores han concedido prioridad a tres facetas: Ia configuración institucional de las Económicas, sus perfiles sociales y sus actividades. En concreto, el segundo de los aspectos aludidos ha suscitado, en los últimos años, múltiples discusiones y análisis. Las principales iniciativas societarias, ¿fueron obra, preferentemente, de la nobleza, el clero y ciertos funcionarios o se debieron también a los burgueses? Y si aceptamos esta segunda hipótesis, ¿cuáles, de entre los prototipos de la burguesía, contribuyeron más a la tarea reformista y regeneradora de los Amigos del País españoles?

1. El debate sobre las Sociedades

Las Sociedades Económicas cuentan ya con una copiosa, aunque no siempre fiable, bibliografía, de la que hemos dado cuenta, en diversos momentos, 
Georges y Paula Demerson', Francisco Aguilar Piñal”, Mariano García Ruipé rez $z^{3}$, Matías Velázquez y yo mismo $0^{5}$.

Uno de los temas que han suscitado la atención de los autores es el de la sociografía de los Amigos del País, y en particular, la presencia y la actividad de los burgueses en las Económicas durante el Setecientos.

En un primer intento aproximativo, pueden apreciarse tres periodos historiográficos - de contornos no siempre bien definidos-: la etapa de los pioneros, la polémica de los años 70 y los estudios recientes.

a) La etopa de los estudios pioneros

Antes de 1950 no se contemplan intentos de análisis sociográfico. Matías Velázquez acaba de recordar, por ejemplo, la vaguedar con que se novía, en 1906, un autor tan característico como R. M. de Labra. A juicio de este ilustre erudito, las Económicas fueron «un centro excepcional donde, a fines del s. XVIII, hombres de todas las procedencias, las categorías y las clases, discutieron los problemas políticos, cconómicos y socialcsy.

Un avance significativo se marca con la obra de Sarrailh. Aunque su España ilustrada", memorable por tantos conceptos, se mueve, sobre todo, en el ámbito de la metodología erudita y la historia de la literatura, no deja de impresionar por la justeza de muchas de sus visiones. En concreto, la composición

G. y P. DEMERSON-F. AGUILAR PINAAL: Las Sociedudes Económicus de Amigos rel País en el s. XVHI. Gúa del imestigador, San Sehastián, 1974. Ohw's particularmente útil.

Aparte la Guía del innestigudor citada en la nota anterios, escrita en colaboración con G. y P. DEMERSON, sus publicaciones fundamentales al respecto son las siguiejtes: «oticia l)ibliográfica de la Real Sociedarl Económica Matritense de los amigos del Pais en el s. XVIII, en Anates del Instinuto de Fstudios Madrileños, VI (1070), págs. 319-349; Bibliografia de la Real Sociedud Fasconguda de los Amigos del Prás en el s. XHWI, San Sebastián, 1071, y Bibliografia de estudios sobre C'rros /I/ y su época, Madrid, 1988. Esta última es fundamental.

M. GARCÍA RUIPEREZ: Nuevas aportncionses al estutio de las Socicdades Económicts de Amigos del Pás, Madrid, 19 gry.

- M. VELAZOUEZ: La Sociedad Econónica de Amigos del Patis del heino de Marcia: la Institución, los Hombres y el direvo (1777-1820), Murcia, 1089 , especialnente, págs. 19-40.

L. M. ENCISO RECIO; "Las Sociedades Leonómicas de Amigos del País*, en VVAA, La época de La Ihustracion. El Estado y la culura (1759-1808). t. XXXI, vol. 1, ale la Historia de Espenant de Menéndez Pidet, dirigida por J. M. JOVER, Madrid, 1984, especialmente, págs, 13-15 y $48-49, y$, del mismo, zLas Sociedades Económicas y el reformismo borbónico en el s. XVIIIs, en VVAA, Carlos H y la histroción, Madri<l, Regl Sociedar Econóntira Matriterse de Amigos del País, 1900, Il, especialmente, págs. 212-230.

- J. SARRALLH: La España ilustrada en la segunda mitad det siglo XFH, México, 1957. 
social de las Económicas fue dibujada por el rector de París con imprecisiones sociológicas y falta de datos cuantitativos, pero acertada y brillantemente.

¿Quiénes trabajaron en favor de los renovadores institutos? «En todas partes -escribe Sarrailh- es lo mismo: unos pocos aristócratas ilustrados, orgullosos de secundar la voluntad del rey y de difundir las luces llevando a cabo en sus propiedades o en sus villas algunas mejoras agronómicas, industriales o escolares; prelados o sacerdotes que ven, en general, en el desarrollo de los métodos técnicos una manera de socorrer a los desgraciados consiguiéndoles trabajo; burgueses, ricos o modestos, empeñados en discutir las teorías económicas, de las cuales tienen algún barniz adquirido casi siempre al azar de sus lecturas en obras extranjeras; algunos especialistas de las ciencias nuevas, química, mineralogía y botánica; a veces, sobre todo en Madrid, algunos filósofos cuya voz es escuchada con deferencia, y, por último, naturalmente, simples comparsas, cuyo eco se apaga tan aprisa como la vanidad que los arrastra al comienzo. Sea como fuere, se puede afirmar que la parte principal de la minoría selecta española figura entre los Amigos del Paíss?

Ninguna novedad fundamental, respecto al tema que nos ocupa, aportó Robert Jones Shafer. Los datos y opiniones del censor de la Económica Valenciana, Pedro Mayoral, le sirvieron para ponderar el papel que desempeñaron en las Económicas diversos grupos sociales, sobre todo, la nobleza, el clero, los miembros de la Administración pública y, en menor medida, intelectuales ilustrados y "persons of the middle class imbued with the current philantropism ${ }^{k}$.

No pocos progresos se registraron en la gran obra de R. Herr, España y la revolución del s. XVIII. El historiador norteamericano valoraba la contribución de clérigos y nobles, pero explicaba que la actividad de ambos sectores no bastaba para explicar el éxito de las Sociedades. «El ímpetu mayor», segúm Herr, «lo dieron plebeyos henchidos de entusiasmo. En 1787 las figuras más ilustres de la Sociedad Económica Matritense eran Campomanes, Cabarrús. Jovellanos -todos estrechamente ligados a los proyectos económicos del gobierno-, Cristóbal Cladera... y Sempere y Guarinos. De los otros 160 miembros, únicamente 10 eran títulos y sólo uno clérigo. A juzgar por las Sociedades Económicas de Amigos del País, tanto de Madrid como de provincias», concluye Herr, «fueron los plebeyos instruidos y los hidalgos sin título los que más decididamente apoyaron los esfuerzos de Carlos III".

J. SARRAILIJ: La Espeña ilustetata, pág. 257.

* R. J. SHAFER: The Economic Societies in the Spanish Hortd (1763-1521). Nueva York, 1958 , pág. 71.

" R. HERR: España y la revalución del siglo XVIII, Madrid, 1964, págs. 136 y ss. 
Los puntos de vista de Sarrailh, Shafer y Herr no se vieron modificados, de forma sustancial, por otros autores de la década de los 60. Rodríguez Casado, a más de situar a las Sociedades en el marco político de las reformas carlotercistas, identificó en las listas de socios a «comerciantes, párrocos, funcionarios, labradores acomodados y nobles ${ }^{10}$. A su juicio, la «fundación de las Sociedades [trajo] como consecuencia el incorporar al sector burgués a las preocupaciones prácticas, dándole un cauce legal para intervenir en la política ${ }^{11}$. Poco añadieron a lo afirmado por otros autores E. Ruiz y González de Linares y M. Bitar Letayf. El primero de ellos ${ }^{12}$ distingue entre los socios a «clérigos, nobles, literatos, artistas y negociantes y Bitar, en su conocido libro sobre Economistas españoles del siglo XIII. Sus ideas sobre la libertad de comercio con Indias ${ }^{13}$, se limita a afirmar que los Amigos del País pertenecieron a todos los grupos sociales.

El catálogo esencial de referencias a la presencia burguesa en las Sociedades se cierra, para el período anterior a 1970, con Alvarez Junco y J. A. Maravall ${ }^{14}$. Este último, en un sugestivo trabajo sobre Las tendencias de reforma política en el s. XVIII», presentaba un nuevo perfil de la cuestión. "Al promover las reformas que nos son conocidas*, decía, a los grupos de las Sociedades Económicas coincidieron con la actitud y los intereses de la clase burguesa en auge. Ellos no son socialmente burgueses en muchos casos con toda la plenitud de significación que esta palabra adquirió en Francia o en Inglaterra, pero si, al modo de Sombert, tomamos como burgués un tipo humano y no un miembro de una clase, tenemos que reconocer que esos grupos de españoles ilustrados pertenecen a la mentalidad del tipo burgués, aunque sacialmente no correspondan al mismo». Por su parte, Álvarez Junco afirmaba que los animadores de la Sociedad Aragonesa de Amigos del País fueron «burócratas, médicos, militares, negociantes y, en menos proporción, universitarios, o sea, un conglomerado" -afirmaba- «no exactamente burgués, por faltarle los intereses y la mentalidad burguesas ${ }^{15}$.

19) V. RODRÍGUEZ CASADO: La politica y los politicos en el reinado de Cartos $\mathrm{II}$, Madrid, 1962, pág. 259.

"V. RODRÍGLEZ CASADO: La política..., pâg. 256.

12 E. RUZZ Y GONZÁLEZ DE LINARES; Las Sociedades Económicos de Amigos del Pais, Burgos, 1972, pág. 11.

${ }^{13}$ M. BITAR LETAYF: Economistas españoles del siglo XIHI. Sus ideas sobre la libertad de comercio con Indias, Madrid, 1968, págs. 17-18.

it J. A. MARAVALL: cLas tendencias de reforma política en el siglo XVIII, en Revista de Occidente, 52 (1967), pág. 60.

1. J. ÁLVAREZ JUNCO: «La Sociedad Aragonesa de Amnigas del País en el s. XVIII , en Revisia de Occidente, 68 (1968), págs. 301-302. 
De una forma u otra, los autores que encabezan la marcha en el proceso del conocimiento de la composición social de las Económicas reconocen la presencia en ellas y la actividad de la burguesía, aunque sólo aducen pruebas parciales y mermadas referencias cuantitativas. Sus hipotesis de trabajo -no siempre bien fundamentadas- y sus afirmaciones apuntaban a que un porcentaje indefinido de los Amigos del País pertenecían a la «burguesía económica o a la ubrguesía intelectual». Pero muchos de los comerciantes. negociantes artesanos, profesionales, intelectuales ofuneionarios a que se alude no sabemos si podían considerarse burgueses o eran, propiamente, mesócratas. Por otra parte, antes de 1970 , apenas si se aclaró nada sobre la mentalidad -y menos la aconciencia de clase - de los burgueses y mesócratas inscritos en las Sociedades, condicionados, en la mayor parte de los casos, por el «espíritu hidalgo».

\section{b) La polémica de los años 70}

En la década de los setenta la historiografía avanzó en dos direcciones confluyentes: el tema de la burguesía y el de las Sociedades Económicas.

a) Los estudios sobre la burguesía

Los estudios sobre la burguesía setecentista española, antes de 1980, obedecieron, según García Baquero ${ }^{16}$, a un triple impulso: el de los modelos de síntesis, el centrado en áreas regionales o locales y el relativo a familias o personalidades burguesas.

En el primero de los sectores aludidos cabe ubicar, conforme a la sugestiva terminología del propio García Baquero, los esquemas interpretativos de los defensores de una «burguesía no burguesa», una «burguesía relativamente burguesa» y una «burguesía progresivamente burguesa».

La construcción básica y más duradera, deducida de las propias investigaciones y reflexiones y divulgada en los manuales de época, fue la ofrecida por Domínguez Ortiz en La sociedad española del s. XVIII $\Gamma^{17}$, ligeramente reelabora-

${ }^{16}$ L. C. ÁLVAREZ SANTALÓ-A. GARCÍA-BAQUERO: «La Sociedad española del s. XVHI: nobleza y burguesía. (Una revisión historiográfica) „, en Coloquio Internacional Carlos III y su siglo, Actas, t. I, Madrid, 1990, págs. 367-386.

17 A. DOMÍNGUEZ: La sociedad española en el s. XVII, Madrid, 1955. 
da posteriormente ${ }^{18}$. Cuatro son sus conclusiones fundarnentales; 1) el número de burgueses fue escaso); 2) la mayor parte de ellos eran comerciantes mayoristas de Sevilla, Cádiz, Madrid, Barcelona y Bilbao, complementados en otras provincias por individuos de lus clases medias, en las que calnia situar a los pequeños comerciantes, el alo artesanado, los funcionarios, y los profesionales; 3) la tipología y la conducta de los burgueses espanoles no son asimilables a las de los ingleses o los franceses, y ello se explica, fundamentatmente, por la debilidad numérica de nuestra burguesía, el escaso aprecio en que la sociedarl española tenía a las actividades burguesas, la débil conciencia de clase de los burgueses hispanos, las dificultades coyunturales de índole económica en que hubieron de desenvolverse y su escusa participarión en el poder municipal y on vias coferas de poder: 4) la *prochividad de la élite burguesa a inerustarke en los modos de vida y cuando fue posible, incluso en las filas ubbiliarias o".

El eco de estas tesis se prolonga en las de Gonzalo Anes. He aquí, clara mente resumidos, sus principales puntos de vista: \&En las ciudades marítimas de la periferia y en algunos núcleos urbanos del interior se consolidó durante el siglo XVII, sobre todo en la segunda mitad, una burguesía dedicada principalmente al comercio y a la producción manufacturera. Esta burguesía, sin cohesión y sin poseer en absoluto conciencia de clase hurguesa en el sentido actual de la expresión, imitaba, a veces, las formas de vida de la motuleza. Los burgueses enriquecidos en el comercio o en la producción manufactureva intentalian, con frecuencia, situar sus ahorros en la compra de tierras» ${ }^{20}$.

Las hipótesis de M. Artola sirven, según Garría Baquero, como material apto para reflexionar sobre la existencia de una «burguesía relativamente burguesa» en la España de finales del Antiguo Régimen². Aún coincidiendo, en lo eseucial, con las formulaciones de Dominguge Oriz. Artula estima que existió untu mentalidad burguesa, expresada, por ejemplo, en las aspiraciones de la burguesid a produeción industrialm, aspectos anbos a los que Anes atribuye connotaciones

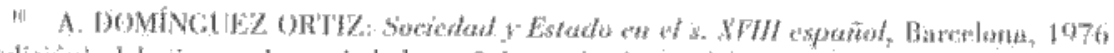

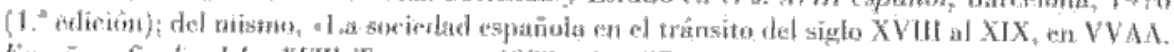

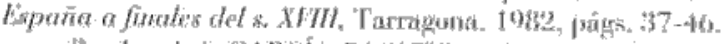
pág. 360 ,

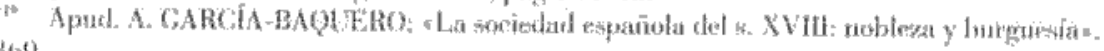

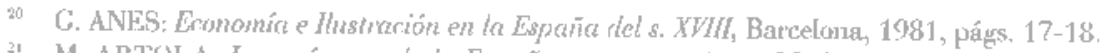

21 M. ARTOH, L: Los origenes de la España contemporánee, Madrid, 1959 ; del nismo. Antiguo Régrmen y rewolución Liberal, Madrid, 1478. 
poco burguesas. Pero lo más original de la argumentación de Artola reside en que, en su opinión, «el mimetismo percibido en las conductas burguesas respecto a las nobiliarias no procedería de una "traición de clase», en el sentido braudeliano, sino,... en cierto modo, de una visión ventajista del rol social (concentrada en exacciones fiscales o acceso a determinados niveles de poder o prestigio social) perfectamente acorde con el supuestamente imprescindible pragmatismo economicista del grupo. En definitiva "-comenta García Baquero-» estaríamos en presencia de una "verdadera» mentalidad burguesa que utiliza las formas de vida nobiliaria como instrumento de escalada social y beneficio económico ${ }^{22}$.

Otros puntos de vista de signo generalizador son los de Josep Fontana, defensor, en opinión de García Baquero, de un modelo de «burguesía progresivamente burguesa». En realidad, el prestigioso historiador catalán fija su atención en la burguesía del siglo XIX y sus inmediatos precedentes. Su opinión se resume en la idea de que «la conciencia de clase [burguesa] apareció cuando resultó imprescindible para garantizar la eficacia del control de la economía». En cierta medida, observa García Baquero ${ }^{23}$ partiendo de los estudios de Fontana sobre La quiebra de la Monarquía absoluta y Cambio económico y actividades políticas en la España del siglo XIX, "podríamos aceptar que su modelo indirecto de la burguesía ilustrada española coincidiría con el de Domínguez Ortiz-Anes en cuanto a negar su conciencia de clase y su papel revolucionario en los procesos de cambio; se apartaría de ellos, presumiblemente, al señalar que tal situación se debió a que los burgueses no sintieron la necesidad de romper unos esquemas en los que disponían de una relevancia socioeconómica y política que consideraron aceptable. Lo que sucedería después correspondería ya a la definición de la burguesía fuera de la Ilustración».

Otros autores, sin pretender eshozar modelos interpretativos generales, aportaron nuevas perspectivas de conocimiento sobre la burguesía setecentista. Es el caso de V. Palacio Atard ${ }^{24}$, a quien se deben anticipadores y lúcidos análisis sobre la mentalidad burguesa, o P. Vilar: ${ }^{2 *}$, uno de los primeros en plantearse,

22 L. C. ÁLVAREZ SANTALÓ-A. GARGIA-BAQUERO: «a soriedad española del s. XVIII: nobleza y burguesía pág. 371.

${ }_{23}$ L. C. ALVAREZ SANTALO-A. GARCIAA-BAQUERO; : La sociedad española del s. XVIII: nobleza y burguesía», jág. 371.

* V. PAIACIO ATARD: •El atractivo uobiliario sobre la burguesía española del Antiguo Régimens, en Hontenaje a J. Fincke, Madrid, 1962-1963); del mismo, a Estilo de vida aristocrático y mentalidad burguesa , en V. PALACIO, Los españoles de ta Itustración, Madrid, 1904, págs. 41115. Véase también su breve estudio fin de la sociedad española del Antigno Régimen, Madrid, 1952.

2: P. VILAR: «Suructures de la société espagnole ver' 1750 , en Mélanges à la memoire de J. Sarrailh, París, 1966, t. II, págs. 425-447. 
a través del análisis del Catastro de Ensenada, una visión de amplio espectro sobre la burguesía. V. Rodríguez Casado ${ }^{26}$, por su parte, arriesgó interesantes -aunque insuficientemente documentadas- hipótesis sobre una pretendida "revolución burguesa en la España del s. XVIII, y propuso algunas pistas para estudiar la enueva sociedad burguesa en la literatura de la época de Carlos III». A Carlos Corona se deben algunas de las reflexiones iniciales en torno a la burguesía finisecular ${ }^{27}$.

Pero durante los decenios 60 y 70 los estudios sobre la burguesía setecentista se polarizaron, sobre todo, en análisis regionales o locales. Algunos de ellos ponían el acento en el grupo social y otros, en cambio, presentaban a los burgueses vinculados a las actividades económicas.

El punto de partida lo marcó el trabajo, tan sugestivo como muchos de los suyos, de J. Vicens Vives ${ }^{28}$ sobre la burguesía catalana. Se preocupaba por definir tres generaciones burguesas, fijar -con criterios restrictivos- la tipología de los burgueses, y explicar la incapacidad del sector para abrir brecha en las estructuras del Antiguo Régimen, a Cuando hablamos de burguesía española entre 1750 y 1833 ", dejó escrito en 1968, «no nos referimos a una clase social inconcreta, como se acostumbra hacer al tratar de este período, sino taxalivantente a los comeruiantes sin almacén abierto y a los fabricantes e industriales del algodón y de la seda. En esta verdadera acepción de la palabra, los únicos estamentos burgueses de España correspondían a los comerciantes gaditanos y a los comerciantes y fabricantes catalanes». Había de pasar tiempo antes de que aparecieran estudios de orientación semejantes, aunque con conclusiones distintas: los de Pere Molas Ribalta.

Cuatro obras significativas jalonaron el despliegue historiográfico de los años 70 sobre la burguesía y sus actividades económicas: La Catalogne dans l'Espagne moderne, de Pierre Vilar ${ }^{29}$; Crecimiento económico y transformaciones sociales en el País Vasco (1100-1850), de E. Fernández de

2 V. RODRÍGLEZ CASADO: «La revolución burguese del s. XVIII español», en Arbor; 61 (1951), págs. 5-30; del mismo, «La nueva sociedad burguesa en la literatura de la época de Carlos IIl, en Estudios Americanos, 100 (1960), vol. XIX, págs. 1-22.

27 C. CORONA, Revolución y reacción en el reinada de Carlos $I V$, Madrid, 1957, especialmente, págs. 60-111

28 J. VICENS VIVES: ‘Coyuntura económica y reformismo burgués. Dos factores en la evolución de la España del Antiguo Régimeñ, en Estudias de Histaria Moderna, IV (1954), págs. 351-391. Ha sido reeditado.

29 Pierre VILAR: La Catalogne dans l'Espagne moderne. Recherches sur les fondements économiques des structures nationales, París, 1962. Se tradujo al catalán, por Ediciones 62, de Barcelona, en 1964-1968 y al castellano, por Editorial Crítica, de Barcelona en 1978-1988. 
Pinedo ${ }^{30}$; La crisis del Antiguo Régimen en Guipúzcoa, 1766-1833. Cambio económico e historia, de Pablo Fernández Albadalejo ${ }^{31}$, y Cádiz y el Atlántico, de Antonio García Baquero ${ }^{32}$.

\section{b) El perfil social de las Sociedades}

A finales de la década de los 60 , singularmente en los años 70 , se planteó también el debate sobre el perfil social de las Sociedades y, más concretamente, la presencia en ellas de la burguesía.

Tres posturas cabe advertir entre los antores: 1) la de quienes conceden relevancia a la aportación burguesa; 2 ) la de aquellos que consideran que la burguesía tuvo una representación minoritaria en las Económicas y, por tanto, su huella fue escasa: 3 ) la de autores que valoran, junto a la acción de los burgueses, la de las clases medias.

En fecha temprana, don Ramón Carande, patriarca por entonces de los historiadores españoles, subrayaba que, en el seno de la Sociedad vascongada convivieron «la nobleza y el clero, con los burgueses, letrados, científicos y artistas». Y, con su característico entusiasmo por los institutos de Amigos del País, comentaba: "Alienta encontrar, reunidos y colaborando a sujetos de distinta extracción y creencias, identificados en el desarrollo del programa ${ }^{33}$.

Esta opinión se vió corroborada por uno de los primeros estudios con datos cuantitativos, el de Georges Demerson sobre la Económica Abulense. Demerson atribuía importancia a la labor que en ella desarrolló lo que ahora denominaríamos «una burguesía desahogada, aún cuando no existía entonces la burguesía como clase, representada por fabricantes, notarios, propietarios, oficiales municipales, etc. ${ }^{34}$

Tal vez quien de modo más decidido exaltaba por estos años el papel de la

30 E. FERNÁNDEZ DE PINEDO: Crecimiento económico y transformaciones sociales en el País Vasco (1100-1850), Madrid, 1974.

3 P. FERNÁNDEZ ALBADALEJO: La crisis del Antiguo Régimen en Guipúzcoa, 1766 1833. Cambio económico e historia, Madrid, 1975.

${ }_{32}$ A. GARCÍA-BAQUERO GONZÁLEZ: Cádiz y el Atlántico (1717-1778), Seville, 1976. Existe una reedición, aparccida cn Cádiz, en 1988.

3 R. CARANDE: EEJ despotikmo itrstrado de Los amigos del País», en Siete estudios de Historia de España, Barcelona 1969, pág. 157. La edición original del estudio es de 1955-1956.

अ G. DEMERSON La Real Sociedad Economica de Amigos del País de Avila (1786-1857), Ávila, 1968, pág. 40. 
burguesía en las Sociedades era Antonio Elorza ${ }^{33}$. En su opinión, la huella burguesa se reflejaba, no sólo en las económicas de la periferia (la Vascongada, la Valenciana, la Mallorquina), sino en algunes del interior (la Matritense y la Segoviana); en todas ellas se registraron "pautas de pensamiento y acción burgueses* * Algunas muestras relevantes de la conciencia burguesa son, a juicio de Elorza, los discursos de Ibáñez de la Rentería, los de Valentín Foronda, Mantel de. Aguirre o Alcalá Galiano, los papeles tercero y octavo de Ias Instituciones Económicas, publicados por la Valenciana, y la Recreación politica de Nicolás de Arricuibar ${ }^{37}$.

Otros estudiosos pomen en duda, o restan valor, a la vinculación de Ios l)urgueses a las Socicdades.

Anes opina, por ejemplo, que los principales promotores, en muchos casos. fueron los nobles o los clérigos, La intervención de la burguesía fue nuinoritaria $\mathrm{y}$, en ocasiones, ni existión . La tesis de Anes se entiende mejor si "se tienen en cuenta dos observaciones suyas»; 1) «En Fspaña, no hubo clase burguesa propiamente dicha hasta avanzado el siglo XIX»; 2), "los ilustrados españoles buscaron una armonía difícil: la de la sociedad estamental con la sociedad burguesa»" Sin embargo, no deja de reconocer «la colaboración, en los institutos de Amigos del País, de las autoridades locales, el funcionariado y los militares". y llama la atención, asimismo, sobre una "mentalidad burguesa, cuyas manifestaciones resulta fácil comprobar en los escritos de los ilustrados del s. XVIII".

Más polémicas se presentan hoy algunas de las alimaciones de Ėrnest

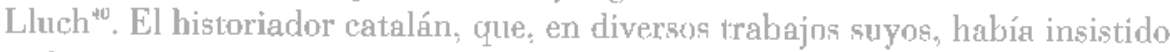
en la participación de nobles, terratenientes y clérigos en lás Sociedades, opina

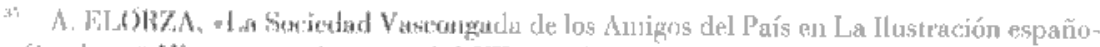

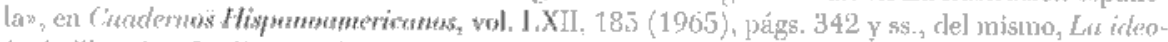

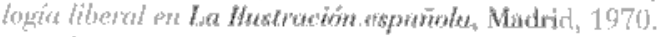

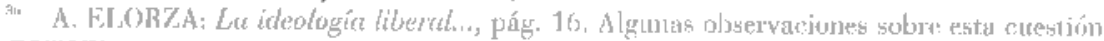
en M. DU IBUSS, «las "Anis du Pays"

${ }^{37}$ Yéase VELAZQQLEZ, o.c. páğg. 195-196.

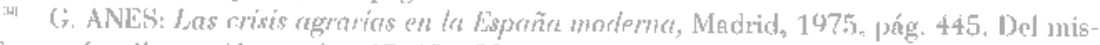
no, Lonomía e llastrución..., págs. 17, 19 y 20

*2 L. M. ENGISO) «Las Sociedades Econónicas" en VVAA, La época de la /lustración. E/ Estado $r$ tr cultura $(1759$ - $1808, \mathrm{t}$. XXXI-1 de la HISTORIA DE ESPANA DE MENENDEZ PIDAL, dirigida por J. M. JOVLR, Madıid, 1987, pág. 52, n. 154.

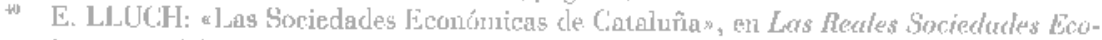

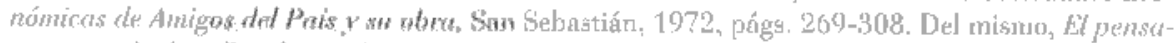

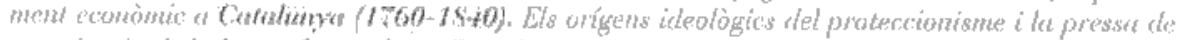

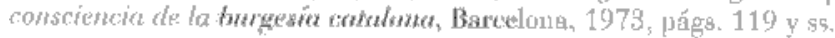


que Campomanes no proyectó las Económicas para la mesocracia y que fueron pocos los burgueses presentes en ellas. Tal realidad no puede extrañar, según Lluch, porque la burguesía propiamente dicha sólo existió en Barcelona. El historiador catalán hace observar también que la burguesía mercantil estaba vinculada a las manufacturas gestionadas por los gremios, y éstos discreparon más de una vez de las Económicas, razón de más para que la mesocracia no se entusiasmara con ellas ${ }^{\dagger 1}$. A este respecto, cabe recordar, como ha hecho F. Aleixandre, que Lluch puso, en su día, de "manifiesto las diferencias existentes entre el proyecto económico latente bajo las Sociedades Económicas y el que trataban de defender las Juntas de Comercio, simplificando mucho los términos, entre lo que llamaríamos posiciones agraristas e industrialistas». Comentando el caso de las Sociedades Económicas de Cataluna, habla de «la inadequació d'unes institucions que no eren ni a l'estil de les Juntes de Comerç ni de les Institucions acadèmiqués i, a mès, molt enmarcades ideològicment» ${ }^{+2}$.

También V. Llombart atribuyó a nobles y clérigos un papel preferente en las Sociedades, de acuerdo con las sugerencias de Campomanes.

Una síntesis de posiciones en torno a la cuestión, acorde con los años en que el trabajo se escribe, puede encontrarse en la tesis de licenciatura de G. López Casares sobre la Económica Murciana, resumida en un artículo posterior ${ }^{44}$.

Una tercera línea interpretativa, sin desconocer la participación de burgueses, puso el acento en la cooperación de las clases medias a la obra de las Económicas. Forniés se refirió, en su día, a los historiadores que «defendían la idea de la existencia de grupos sociales componentes de las clases medias, que manifestaron a lo largo de su intervención destacada en las Sociedades Económicas rasgos inequívocos de mentalidad burguesa». El propio Forniés advirtió que muchos de los socios de la Aragonesa "pertenecían a las clases medias tanto por su poder adquisitivo como por su nivel cultural $\$$.5.

" M. VELÁZQUEZ, o.c. pág. 195.

*2 Apud. F. ALEIXANDRE, La Real Soctedad Económica de Amigos del País de Futencia. Marco jurulico, estructure social y financiación (17r6-1533), Valencia, 1983, pág. 96.

t3 V. LLOMBART: Absolutismo e ilustración: la pónesis de las Sociedades Económicas de Amigos del Pás, Valencia, 1979, pág. 10.

* G. LOPEZ CASARES: Las Sociedades Eronómicas de Amigos del País: el caso de Murcin, presentado en la Universidad de Valencia en 1973. Véase también su artículo « Ia Sociedad Econónica de Amigos rel País de Murcia (1777-1808)*, en Anales de Economía, enero-junio de 1975, ns, 25-26, págs. 39-63. Apud. F. ALEIXANDRE, o.c., pág. 97.

t5 J. J. FORNIES: "La estructura social de los Amigos del País en Aragón*, en Boletín de Documentación del Fondo para la Thvestigación Económico y Sociah, vol. IX, fasc. 2." (abril-junio 1977), págs. 3 y 58. 
Postura más ecléctica es la de Domínguez Ortiz, para quien los altos funcionarios - a los que atribuye capacidad intelectual y material suficiente para ser considerados miembros de la clase burguesa- «juntamente con hidalgos y clérigos, formaron, espontáneamente o a consecuencia de discretas presiones llegadas de arriba, el núcleo de las Sociedades Económicas que pulularon por iniciativa de Campomanes* ${ }^{46}$. No otorga tanta importancia a los comerciantes. tal vez porque no le parece que los comerciantes, en general, puedan calificarse propiamente de burgueses, 0 , al menos que tuviesen mentalidad burguesa, ya que «su máxima aspiración era vivir noblemente, casar con hidalgas, adquirir un título, abandonar los negocios y, al cabo de algunas generaciones, hacer que se olvidase el origen de la fortunas ${ }^{47}$.

Pese a que las discusiones no se vieron acompañadas por un definitivo impulso de la investigación, en la década de los 70 se registraron ya positivos avances en el conocimiento de la fisonomía social y actividades de las Económicas.

c) Los primeros análisis sociográficos

Demerson $^{49}$ ha sido precursor, en cierto grado, de los análisis sociográficos.

En relación con la Económica de Ávila, explicó, en fecha temprana, el papel que jugaron en la entidad los individuos vinculados a diversos grupos sociales y actividades profesionales.

En las listas de socios asistentes a las juntas correspondientes a 1786 figuran 37 eclesiásticos y ocho autoridades territoriales o municipales -el corregidor, el teniente de alférez mayor, varios regidores perpetuos, el administrador de Rentas provinciales, el de Salinas y el contador de la provincia, el administrador de Correos y el procurador de la Tierra. Dos años después -en 1788había 141 socios, de los cuales 108 habían abonado el importe de la cuota, pero Demerson sólo pudo identificar a 85.

A más de los párrocos de la diócesis y los 17 «socios de honor»-entre ellos, consejeros de Hacienda o del Departamento de Fomento y Balanza- y 9 correspondientes nobles, figuraban en las filas societarias 34 funcionarios de la Administración -oficiales primeros o segundos, administradores, secretarios del

16. DOMINGUEZ ORTÍZ: Sociedad y Estado, pág. 395.

$"$ Ibid.

10 G. DEMERSON: La Sociedad Econámica de Amigos del País de Anila (1756-1857), Avila, 1968 . 
Gobierno de Ávila-, algunos de los cuales se inscribieron, tal vez, «por orden superior...".

En suma, «las personalidades más activas de la Abulense fueron, a juicio de Demerson, burgueses o mesócratas -fabricantes, notarios, escribanos, propietarios, oficiales regios, oficios municipales- eclesiásticos... y, en reducida proporción, los nobles ${ }^{49}$.

Nueve años después de que apareciese la obra de Demerson, J. J. Forniés dio a la luz un enjundioso trabajo sobre «La estructura social de los Amigos del País en Aragón ${ }^{50}$, previo a la publicación de su valioso libro sobre la Aragone$\mathrm{sa}^{51} \mathrm{y}$ otros estudios complementarios.

«Desde marzo de 1776 hasta el mes de junio de 1868, explica Forniés, la Real Sociedad Aragonesa contó como socios a un total de setecientas ochenta y cinco personas $\star^{52}$. La falta de precisiones cronológicas impide un análisis de los distintos períodos en la evolución de la entidad. ¿̧A qué sectores sociales pertenecían las 785 personas aludidas?:

Cuadro I. Porcentajes de los grupos sociales en La Aragonesa

\begin{tabular}{lr}
\hline Nobleza titulada & $10,83 \%$ \\
Clero secular & $25,36 \%$ \\
Clero regular & $2,16 \%$ \\
Reales Ejército y Armada & $5,6 \%$ \\
Administración civil & $22,17 \%$ \\
Profesionales de la Enseñanza & $4,20 \%$ \\
Profesiones liberales & $10,83 \%$ \\
Propietarios agrícolas & $12,73 \%$ \\
Fabricantes & $0,77 \%$ \\
Comerciantes & $1,79 \%$ \\
Sin datos & $3,50 \%$ \\
\hline
\end{tabular}

Fuente: J. J. Forniés, «La estructura social», p. 21.

49 Ibid

so J. F. FORNIÉS CASALS: "La estructura social de los Amigos del País en Aragón», en Boletín de Documentación del Fondo para la Investigación Económica y Social, vol. IX, fasc. 2. (abril-junio 1977). Cito por la separata

${ }^{51}$ J. F. FORNIÉS CASALS: La Real Sociedad Económica Aragonesa de Amigos del País en el periodo de La Ilustración (1776-1808): Sus relaciones con el artesanado y la industria, Madrid, [1978], pág. 21.

52 J. F. FORNIÉS: «La estructura social», pág. 4.. 
Los nobles inscritos fueron 85, lo que supone un 10,8\% del total de socios. e influyeron no poco en la institución. Más decisivo fue el papel del clero -sobre todo, el secular-, de cuyas filas salieron 216 socios -esto es, un $25,36 \%$ del total de socios.

Un núcleo fundamental de la burguesía lo formuban los hacendados -o propietarios agrícolas-, los comerciantes y los industriales. Con laudable franqueza, Forniés advierte que en este epígrafe incluye sólo a "aquellos que, además de pertenecer al estado llano, son citados expresamente como propietarios, industriales, comerciantes y residentes -o sea, hacendados - y no los "mumerosos nobles, clérigos regulares y seculares, funcionarios, etc, que simultaneaban sus acividades con las agrícolas y ganaderas, principalmonte, y en menor medida con las industriales y comerciales ${ }^{\text {s. }}$. El criterio usado para clasificar a estos últimos grupos es el de confinarlos a sus categorías estanentales.

La preponderancia del sector agrícola y ganadero en la Sociedad queda explicada por el hechu, de que en 1797, propietarios, arrendatarios y jornalerus sumaban un $38,6 \%$ de la población activa, añadido a la circunstancia de que el $6,4 \%$ de los habitantes de Zqragoza tenían relación con el campo. Nada extraña, pues, que labradores, ganaderos, hacendados y «residentes» estuvieran representados en la Aragonesa por 98 socios.

Muy otro es el caso de los inclustriales. Si el componente, aragonés dedicado al sector secundario de la economía superó, a lo largo del siglo, el $15 \%$ del total de población activa, Ios socios de la Aragonesa vinculados a la industria fueron 6 -dos fabricantes textiles, un alfarero, un fundidor de bronce, un relojero y un joyero- y, por tanto, no sobrepasaron el 0,77\%.

I.a "burguesía económica* se complcta con los conterciantes. Su rupresentación en la Sociedad Aragonesa es pequeña: 14 personas, lo que equivale al $1,79 \%$ del total de los socios. La cifra contraste con la implantación de la actividad comercial en Aragón, estimada por algunos entre un 14,8\% (1797) y un $19,7 \%$ (1787) de la población activa. Entre los inscritos en la Sociedad figuraban Ionjistas -comerciantes al por mayor-y, probablemente, «corredores de oreja» -intermediarios que "controlaban todas las mercancias agricolas, mineras y artesanas que llegaban a la ciudad y que no eran objeto de legislación diferenciada ${ }_{-34}{ }^{34}$ comerciantes al por menior y miembros de la Rcal Com-

53 J. F. FORNIÉs: «La estructura socials, pág. 10.

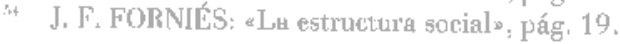


pañía de Comercio y Fábricas de Zaragoza o de la Compañía de Amigos de Zaragoza. De ellos, no todos pueden ser calificados de burgueses.

El peso de los funcionarios en la Aragonesa, como puede imaginarse, fue notable. Forniés ha identificado 174 , cifra que supone un $22,17 \%$ del total de socios. Más de la mitad de estos personajes -el 51,14\%-pertenecían a la Administración de Justicia, cuyo enorme influjo en Zaragoza vino motivado por la creación de la Real Audiencia. Entre los miembros de los órganos judiciales cabe citar a un regente de Audiencia, fiscales escribanos de Cámara, un inquisidor fiscal, ministros del crimen, oidores de la Audiencia, un agente fiscal de la Real Cámara de Castilla, alcaldes del crimen, abogados de la Real Audiencia, un procurador de la Audiencia, un maestresala de Justicia, un teniente canciller mayor de la Audiencia, un alcalde de las Reales Cárceles, un alguacil mayor de la Inquisición, relatores de lo civil de la Audiencia y relatores de lo criminal en la Audiencia. Vinculados a la Administración central estaban los miembros de los consejos: 44 abogados de los Reales Consejos, un fiscal del Consejo de Castilla, un inquisidor general y oficiales de la secretaría de Estado.

Otro grupo nutridamente representado era el de la Administración hacendística, que sumaba un 10,34\% de los funcionarios. En él figuraban el propio secretario de Estado y Despacho de Hacienda, el fiscal de la Real Hacienda, dos administradores generales de Rentas Reales y diversos funcionarios residentes en Zaragoza-Administradores de Lotería, administrador principal y tesorero de Temporalidades, el de la Real Aduana, el de las Rentas de Bulas y Papel Sellado, contadores, un representante de la Junta de Comercio y Moneda, oficiales de la Contaduría del Catastro y de la Gracia del Excusado, receptores, un recaudador de la Real Contribución y visitadores de lanas-. Muchos de estos individuos pertenecían más a las clases medias que a la burguesía.

En la Aragonesa había también múltiples representantes de la Administración territorial y local-más de un $20 \%$ del total de funcionarios socios-. Subrayemos la presencia de dos intendentes, cinco corregidores, ocho alcaldes mayores, veinte regidores de Ayuntamiento, dos secretarios de Ayuntamiento y un oficial de la Contaduría de Propios. De ellos, algunos eran nobles, otros burgueses y unos terceros, probablemente, gentes de clase media.

El capítulo de los profesionales de la Económica de Aragón lo divide Forniés en dos epígrafes: profesionales de la enseñanza -sobredimensionados en la entidad respecto a los existentes en Zaragoza- y profesionales liberales.

Entre los primeros, cuya cuantía se elevaba al 4,2\% de los socios, se ha podido identificar a 12 catedráticos de la Universidad de Zaragoza -de las 
Facultades de Artes, de Cánones, de Leyes, de Medicina y de Teología-, varios profesores de la Real Academia de San Luis y de las restantes escuelas dependientes de la Sociedad, profesores de los Estudios Reales de la Gorte o de Aulas reales de la ciudad y otros profesores residentes en Madrid, París y Bolonia. Los más, pertenecían a las clases medias.

La panoplia de profesionales liberales -85 personas- era amplia. Los más próximos a la burguesía eran los abogados (9), doctores en Cánones (8), los médicos (14), doctores en Derecho Civil (3), los boticarios (3), los arquitectos (3) y, tal vez, los botánicos (4), notarios (3), cirujanos (5) y agentes de la Sociedad en Madrid (2). Otros socios de este sector pueden ser calificados de mesócratas. Es el caso del administrador del Canal Imperial, administradores particulares, el aparejador del Canal Imperial, pintores, secretarios particulares o un encargado de minas. Más difícil es clasificar a los alumnos, bachilleres, un colegial mayor y las damas. Estas últimas eran, en realidad, de familias aristocráticas.

Fornićs fue uno de los primeros en poner de relieve la diferencia existente entre los socios inscritos, pero no comprometidos en las tareas de la Sociedad, y los verdaderamente activos y emprendedores. Para ello, revisó las 1.565 juntas reunidas entre 1776 y 1868 y contabilizó 19.648 asistencias de socios a las mismas. Divididos por sectores sociales, los asistentes registraron estos porcentajes:

Cuadro II. Porcentajes de asistencias de grupos sociales en la Aragonesa

\begin{tabular}{lr}
\hline Nobleza títulada & $4,49 \%$ \\
Clero secular & $26,43 \%$ \\
Clero regular & $0,99 \%$ \\
Reales Ejército y Armada & $5,64 \%$ \\
Administración civil & $31,71 \%$ \\
Profesionales de la Enseñanza & $8,05 \%$ \\
Profesiones liberales & $14,25 \%$ \\
Propítarios agrícolas & $2,60 \%$ \\
Fabricantes & $-\%$ \\
Comerciantes & $5,32 \%$ \\
Sin datos & $0,52 \%$ \\
\hline
\end{tabular}

A través de las cifras manejadas se puede llegar a la conclusión de que la nobleza se mostró irregular en sus compromisos societarios: fue asidua entre 1776 y 1783 , y en los años siguientes, trabajó poco. 
Entre los eclesiásticos, el clero secular «observó una gran regularidad en su comportamiento", sobre todo, desde 1790 a 1808 , pues apenas existen diferencias entre los porcentajes de inscripción $(25,3 \%)$ y de asistencias $(26,4 \%)$. Mucho más remiso fue el clero regular, como se acredita en el desnivel entre el porcentaje de inscripciones $2,16 \%$ - y el de asistencias -0,99\%-. Durante nueve años su incomparecencia fue total.

De la «burguesía económica» los más activos fueron los comerciantes, cuyo porcentaje de asistencias $(5,32 \%)$-declinante entre 1783 y 1790 - fue muy superior al de inscripciones $(1,79 \%)$. Muy otro es el caso de los propietarios agrícolas -muchos de ellos residentes fuera de Zaragoza-, cuyo índice de asistencias es bajo $(2,6 \%)$, y los fabricantes, ausentes de las juntas, si se exceptúa a dos industriales de Albarracín, funcionarios y, a la vez, propietarios de fábricas.

Los que se sintieron más próximos a la Sociedad -a la que consideraron, probablemente, un marco idóneo para su promoción política- fueron los funcionarios. Su porcentaje de asistencia $(31,7 \%)$ fue superior al de inscripciones $(22,17 \%)$, y su compromiso se hizo más intenso entre 1783 y 1790 , los años en que se publica un Plan Gremial contrario a las estructuras artesanales tradicionales y se suscita la polémica sobre la cátedra de Economía Civil y Comercio de la Sociedad.

Los profesionales de la enseñanza, alcanzaron un nivel más alto de asistencias $(8,05 \%)$ que de inscripciones $(4,2 \%)$, y ello puede explicarse por la labor docente que emprendió la propia Sociedad. Un claro entusiasmo se reflejó también en el sector de los profesionales liberales, favorables a «las reformas* y cuyo índice de asistencias $(14,2 \%)$ superó asimismo al de inscripciones (10,8\%).

En cuanto a los militares, se mostraron, en éste como en otros campos de actividad, disciplinados, y de ahí su estimable nivel de participación.

En suma, las responsabilidades esenciales de la Aragonesa las asumieron los funcionarios, los profesionales y los comerciantes, los sectores más burgueses o proclives a la burguesía, y el clero. Ello expresa la capacidad potencial de cambio que se encerraba en la entidad.

A fin de cuentas, la polémica sobre la relación entre la burguesía y las Sociedades aportó pocos argumentos concluyentes en la década de los 70. Con razón observaba V. Llombart: "no podemos obtener conclusiones definitivas... hasta no disponer de estudios concretos y con criterios modernos sobre las distintas Sociedades". ${ }^{55}$

55 V. LLOMBART: Absolutismo e ilustración, págs. 13-14. 
Este objetivo se cumplió, hasta cierto punto, en la década de los 80 , periodo en el que también conocieron un notable desarrollo los estudios sobre la burguesía.

\section{c) Los estudios recientes}

El punto de partida de las nuevas síntesis interpretativas lo marcó, de nuevo, Domínguez Ortiz en su libro Sociedad y Estado en la España del s. XVIII. ${ }^{56}$

\section{El fenómeno burgués}

Escasas rectificaciones presenta esta obra respecto al debatido tema de la burguesía. Sin embargo, por lo menos dos, me parecen dignas de ser tenidas en cuenta. La primera es que «la definición del burgués no es sólo una cuestión de status económico o social que pueda resolverse aplicando criterios de cuantificación. Es imprescindible también el estudio de las mentalidades porque «sóln es burgués quien se considera á sí mismo un burgués» y, si hubo numerosos mereaderes de mentalidad estamental, encontramos en cambio personajes representativos de la mentalidad burguesa en la alta y media nobleza, entre los funcionarios y en el clero secular». ${ }^{57}$ Esta llamada a servirse del análisis de la mestalidad para hacer luz en la polémica se acompaña con el reconocimiento de la relativa importancia que alcanzaron dos tipos a los que puede calificarse de burgueses: los maestros emprendedores de la Barcelona finisccular que, "comtra las reglas establecidas por los gremios, se convirtieron en auténticos indus-

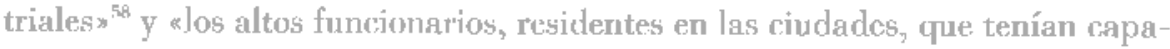
cidad intelectual y material suficiente para ser considerados miembros de la clase burguesan. ${ }^{5 n}$

Pere Molas, que ya había mostrado en trabajos anteriores su interés por la cuestión, ofreció, en su libro sobre La burguesía mercantil en la España del Antiguo Régimen, ${ }^{60}$ una renovadora visión de conjunto y no pocas precisiones de detalle sobre el burgués del comercio y su mundo.

A más de proporcionar pistas básicas sobre el significado del término

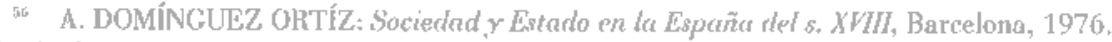
Reedición de 1981.

A A. DOMINC;UEZ: Sorcipdad y Estado, pág. 400.

A. DOMÍNGUEZ: Sociedad y Estado, pág. 392.

s. AOMÍNGURZ: Sociedad y Estadu, pág. 394.

(4) P. MOLAS RIBALTA: La burguesa mercantil en la España del Anriguo Régimen, Madrid, 1985. 
burgués en el Antiguo Régimen ${ }^{61}$, brindó un análisis tipológico del patriciado urbano, las profesiones liberales, la burguesía mercantil y la burguesía industrial en la Europa moderna. ${ }^{62}$

«El comercio constituía, todavía en el s. XVIII, la principal base de los ingresos de la burguesía». ${ }^{63}$ La característica fundamental del comerciante del Antiguo Régimen español era su polivalencia, es decir, una falta de especialización en un tipo de comercio, producto o actividad determinada». ${ }^{64}$

Molas ha puesto especial afán en definir a los «mercaderes de lonja» y a los "mercaderes de vara», cuya diferenciación se ahondó en el s. XVIII. ${ }^{65}$

Los primeros, «llamados a veces lonjistas, eran los verdaderos comerciantes o negociantes, caracterizados por el ejercicio de su actividad en tienda cerrada, lonja o almacén». El «trato o negociación» superior tenía consecuencias jurídicas, como, por ejemplo, el acceso a los consulados -en los que sólo después de 1784-1786, y bajo la influencia de Campomanes, fueron admitidos los comerciantes al por menor-o la compatibilidad con la nobleza.

Quienes se dedicaban al «comercio de un tipo concreto de productos (mercaderes de paños, de sedas, etc.)", y lo hacían al por menor, "vareando», eran denominados "mercaderes de vara".

Pese a las limitaciones jurídicas y sociales que afectaban a los pequeños comerciantes y a las connotaciones negativas que adquirieron éstos en ciertos sectores, protagonizaron una actividad económica notable y cubrieron un espacio entre los lonjistas y los artesanos. "Socialmente formaban una élite corporativa de gremios mayores». «Los gremios mayores de otras capitales -Zaragoza, Valladolid, Pamplona, Toledo, Valencia, Cuenca, Murcia, Cranadainfluenciados por las ordenanzas madrileñas y por el impulso de los cuerpos de comercio de Barcelona, acabaron sustituyendo su antigua denominación por la de cuerpos generales de comercio». La nueva institución tuvo una vida brillante hasta $1780,{ }^{66}$ en cuya fecha la posibilidad de acceder directa e individualmente a las matrículas de comercio la privó de su razón de ser.

${ }_{61}$ P. MOLAS: La burguesía mercantil en la España del Antiguo Régimen, págs. 17-19.

6. P. MOLAS: La burguesía mercantil en la España del Antiguo Régimen, págs. 17-46.

3. P. MOLAS: «La actitud económica», pág. 101

"P. MOLAS: "La actitud económica», pág. 108.

tis P. MOLAS: La burguesía mercantil en la España del Antiguo Régimen, págs. 46-81.

6. Sobre la pequeña burguesía mercantil y los cuerpos generales de comercio, P. MOLAS, La burguesia mercantil, págs. 67-110; y L. M. ENCISO, P. Molas y la Historia social de la Adninistración, en P. MOLAS, Consejos y audiencias durante el reinado de Felipe II, Valladolid, col. Síntesis, 1984, pág. 40. 
¿Cuáles fueron las actividades económicas del pequeño comercio? «El foco central de acción era el comercio de tejidos, seguido e importancia por los de especias, drogas y joyería. El pequeño comercio textil abarcaba las variedades clásicas de lana, seda y lienzos. A ellas se añade ese tipo de venta miscelánea que es la mercería -tejidos de seda y lienzos..., medias, sombreros, papel e incluso colorantes-... La joyería, las especias, drogas y productos coloniales, el hierro, cerería y confitería estaban integrados o segregados, según los casos, en los gremios mayores y en los cuerpos de comercio. A veces, los cuerpos generales y los gremios -sobre todo, los de Madrid-promovicron, o se propusieron pronover, "artes y fábricas» y auxiliar a a artistas, fabricantes y labradores»."

Tres notas más caracterizan, según Molas, a los «cuerpos generales de comercios: el influjo del factor religioso en la vida corporativa, la existencia de una jurisdicción propia y la mentalidad estamental. En cuanto a su formación intelectual, solía centrarse en el conocimiento de los libros mercantiles, de las cuentas, pesos y medidas y de los vales y letras de cambio.

Otro sector de comerciantes y negociantes dedicó atención preferente a colaborar con la Monarquía o con los estamentos privilegiados. «Los arrendamientos de derechos señoriales y de diezmos, el arrendamiento de impuestos, "los asientos» o contratos de suministros estatales, sobre todo militares (de alimentación, vestuario, transporte, etc), los contratos de abastos e impuestos municipales eran campo de acción de los grandes comerciantes». Al Algunos de estos burgueses, de mentalidad tradicional, se dejarom ganar por el inmovilismo en lo económico y el afán de ennoblecimiento. Esto ocurrió, según ha demostrado Eiras," en Santiago de Compostela, o, tal, y como acreditan Alvarez Santalo y García Baquero, ${ }^{70}$ en Sevilla. También se ha amalizado el caso -bien definidode los asentistas vascos y navarros vinculados a la Administración del Estado."

o7 L. M. ENCISO: «P. Molas y la Historia social de la Administración », pág. 41. Tambión, P. MOLAS, *La actitud » pág. 110.

${ }_{6}$ P. MOLAS: aLa actitud», pág. 102. CARMEN SANZ AYÁN-๙La burguesía financiera de. Andaluría a comienzos de] s. XVIII: origenes, afianzamiento e intereses , en La burgutestu de negocios en ha Andulucír de la Ilustración, Il, páps. 139-149- ha explicado bien los perfiles de una whurguesía financiera* en la España de comienzos de] s. XVIII. Sus capitales provenían del comer. rin-en peqqueña medida-y de log préstamus a la Ciorona. A través de estos últimos, obinvieron el manejo te las rentas reales -sobre todo, en Andalucia- y se introdujeron en la Adninisiración a medida que su importancia aumeritaba, C, SANZ ve concomitancias entre esta burguesia y la francesa.

(*) A. EIRAS ROEL: La burguesía mercantil compostelana a mediados del s. XVIII , en La Historia social de Galicia en sus fuentes de protocolos, Santiago, 1981, págs. $521-564$.

70 ÁLVAREZ SANTALO-GARCÍA-BAQUERO, \& Funcionalidad del capital anılaluz en v'isperas de la primera industrialización», en Estudias regionales, 5, jágs. 101-133.

J. CARO BAROJA: Les hom saverra del s. XIII, Pamplona, 1969. 
«El nivel superior del comercio estaba representado por el giro, es decir, por la utilización de las letras de cambio y... las finanzas». ${ }^{72}$ Sin embargo, el giro de letras, utilizado por «los comerciantes al por mayor o banqueros», ${ }^{73}$ era practicado también por los mercaderes de vara. ${ }^{74}$ Dentro de la pequeña burguesía cabe ubicar asimismo al "gremio de corredores de lonja, que a veces se titulaban explícitamente corredores de cambio. ${ }^{75}$ En cambio, las compañías de seguros por acciones de Barcelona y Madrid estaban dirigidas e integradas por los principales miembros de la alta burguesías. ${ }^{76}$

El propio Molas y González Enciso ${ }^{77}$ han abierto pistas reveladoras para el estudio de la burguesía industrial.

Mientras pervivió el domestic system tuvo especial protagonismo el mercader-fabricante. Se llamara como se llamase, el empresario de origen mercantil dio vida a la industria «dispersa». «Proporcionaba -como dice Molas- a los artesanos, formalmente independientes, capital y materia prima, y recogía luego la producción para comercializarla y obtener un beneficio». Con él colaboraban artesanos, relativamente autónomos, que elaboraban casi todo el producto, y mano de obra campesina, de dedicación parcial y no obediente, por lo común, a las reglas gremiales. Pero la dedicación de los empresarios aludidos a las actividades propiamente industriales era aleatoria. Sus principales inversiones seguían realizándose en el comercio, en las especulaciones financieras o en la adquisición de tierras $\gg-{ }^{78}$.

A más del empresario, otra figura importante del viejo sistema era la del fabricante -principalmente, de paños-, de capital reducido, pero de amplios conocimientos técnicos y gran experiencia. Eran los denominados *pelaires», en Castilla, y aparaires», en Cataluña.

72 P. MOLAS: «La actitud», pág. 110.

73 P. MOLAS, Comerç i estructura social a Catalunya $i$ Valencia als segtes XVII $i$ XVIII, Barcelona, 1977, págs. 46 y 378. También, MOLAS, «La actitud», pág. 110.

${ }^{74}$ P. MOLAS, «La actitud s, pág. 110. Remite a sus obras Los gremios barceloneses en el $s$. XVIII, Barcelona, 1975, págs. 79-80.

75 P. MOLAS: «La actitud», pág. 110. Remite a la tesis de M. T. RODRIGO, de la que se ofrece un resumen en Pedralbes, 6 (1980).

76 P. MOLAS: "La actitud», pág. 111. remite a P. VILAR, Catalunya dins l'Espanya Moderna, IV, págs. 533-539; MOLAS, Comerç, págs. 249-296; M. J. MATILLA, «Las Compañías privilegiadas en la España del Antiguo Régimen», en M. ARTOLA (ed), La economía española al final del Antiguo Régimen, IV, Instituciones, Madrid, 1982, pág. 392.

77 A. GONZÁLEZ ENCISO: *Aspectos del proceso de industrialización en la España del siglo XVIII», en Annali della Facoltà di Economia e Comercio della Università di Bari, Nuova Serie, vol. XXVII, 1988, págs. 95-146.

${ }_{7 \sharp}$ P. MOLAS, La burguesía mercantil, págs, 34-35. 
Con la revolución industrial, muchos artesanos-fabricantes mostraron resistencia a las innovaciones, y quedaron reducidos a trabajadores de las fábricas. También cambió el horizonte para el antiguo empresario. La tecnología, la concentración de capital y la concentración del trabajo, cn lugares o instalaciones determinados, requerían un nuevo "capitán de industria». En España tuvieron un papel no desdeñable, aunque contradictorio, como han acreditado Conzález Enciso y Helguera, ${ }^{79}$ los promotores extranjeros.

Hacia 1760, en opinión de Molas, todo empezó a cambiar. En Cataluna. por ejemplo, al establecerse las primeras lábricas de indianas, la nueva irdustria caminó gracias a la alianza del capital - a veces, de procedencia mercantily la habilidad técnica de un artesano especializado, al que se denomina fabricante. Este último solía participar en beneficios o cobraba un sueldo. Si aportaba capital propio, recibía una cantidad suplementaria por su trabajo técnico y de dirección.

A fines del Setecientos, la burguesía industrial, al decir de Molas, se centraba en la "producción, polarizada por la fábrica, la cual exigía una dedicación permanente y fuertes inmovilizaciones de capital y, en las primeras etapas, und reinversión Inasiva de los beneficios". También era nueva la situación social de los burgueses relacionados con la industria. «Los cambios políticos -escribe Molas- suscitaron nuevas coordenadas sociales, que permitían al fabricante burgués sentirse satisfecho con su lugar en la sociedad, y que le obligaban a abandonar su empresa para ascender en la escala social».

En resumen, Molas afirma que, en muchos casos, la burguesía industrial no procedía directamente de la antigua burguesía mercantil o de negocios, la cual se vió esterilizada, en ocasiones, «por culpa de las inversiones improductivas, el afán de ennoblecimiento, el atractivo de la burocracia o las especulaciones financieras vinculadas a los fundameratos de la sociedad estamental».

Un último prototipo de burguesía económica se alojaba en el área rural. Molas no dedica a este sector particular atención, pero subraya que la burguesía era también propietaria agraria. Para acreditarlo, trae a recuerdo algunos ejemplos -analizados por él- de Mataró y los datos que Vilar proporciona sobre los intereses agrarios de los comerciantes de Barcelona. ${ }^{\text {nus }}$

7" J. HELGUERA: La industria metalúrgica experimental en el siglo XVHI. Las heales Fábricas de San Juan de Alcurtz, 1772-1800, Valladolid, Estudios y Documento (XIJII), 1984.

* P. MOJAS, Socielcal i poder politica a Mataró, 1718-1808, Mataró, 1973, págs. 21-42;

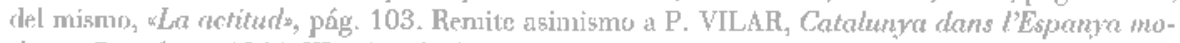
dema, Barcelona, 1966, III, págs. 276-278. 
Molas ha abierto también nuevos horizontes para el análisis y la discusión sobre la que podríamos denominar aburguesía intelectual».

"Una parte importante de la burguesía del Antiguo Régimen -ha escrito- estaba constituida por los... graduados universitarios. La Universidad daba títulos, fundamentalmente, además de a los teólogos, a juristas y médicos. Una proporción considerable de los graduados en leyes (Derechos Canónico y Civil) hallaba su salida en el servicio administrativo del Estado o de los municipios. Quedaba, para quienes no entraban en el servicio público, el libre ejercicio de la profesión ". ${ }^{81}$ Con razón advierte Molas que, «en zua sociedacl que clusificaba a los hombres más según criterios de consumo que de producciôñ es lógico coscedes atención, desde la perspectiva de la historia social, a las profesiones. Fn csa línea tienen interés los recientes estudios, entre otros; de M. Torremocha ${ }^{\text {yt }}$ y J. M. Navas. ${ }^{\text {8:3 }}$ Dentro del amplio elenco de los prof́esiomules el rnngo más alto lo alcanzaban los doctores en Derecho y Medicina, asimilados, en ciertos casos, a la nobleza.

Un sector en cuyo análisis social se ha avanzado muy poco es el de los «intelectuales»-escritores, pensadores, periodistas y otros tantos prototiposentrevista más bien a través de sus vínculos con la Ilustración. ${ }^{.4}$ Diversos trabajos nos permiten, como ha recordado Aguilar Pañal, «conocer los libros que poseían arquitectos como Ardemans; escultores como Felipe de Castro; políticos como Bruna, Olavide y Campomanes; eruditos como Feijóo, Sarmiento, Mayans o Flórez; aristócratas como cl conde del Aguila o el marqués de Narros; comerciantes acaudalados como el gaditano Sebastián Martínez; literatos como Meléndez Valdés, Isla o Jovellanos». ${ }^{\text {pr }}$ Por no referirse sino a una aportación significativa recordemos el que ha dedicado García Baquero a la biblioteca de Sebastián Martínez, ${ }^{86}$ en el que se abren interesantes vías

${ }^{3}$ P. MOLAS: La burguesia mercantit en la España del Antiguo Régimen, pág. 23. Remite. al conocido libro de R. KAGAN, Univer'sidd y sociedad en la España moderna, Madrid, 1981.

a2 M. TORREMOCHA, «La formación de los letrados en el Antiguo Régimen», en I Jornadas de exercicios dos poderes na Europa du Stu. Secs. XHII-XHIII. Lisboa, 1988.

a. J. M. NAVAS: Los abogados y los oficios de. Justicia en la Castilla del s. XVII, Madrid, 1991, págs. 383 y ss. Tesis inédita dirigida por el Dr. J. López-Salazar.

at L. M. ENCISO: "La Ilustración en España, en Actas del Coloquio Internacional sobre Carlos III y su siglo, Madrid, 1990, págs. 621-697. Véanse también los sugestivos análisis de J. ÁLVAREZ BARRIENTOS; «El hombre de letras españols, en Actas del Congreso Internacional sobre Carlos III y la Ilustración, Madrid, 1989, t. III, págs. 417-426, y eEl periodista en la España del siglo XVIII y la profesionalización del escritor", en Periodismo e llustración en España. Estudios de Historia Social, n. ${ }^{\circ}$ 52-53 (1900), págs. 29-41.

5 F. AGUILAR, Introducción al siglo XHII, Madrid, 1991, pág. 149. El libro forma parte de la Historia de la Literatura Española, dirigida por R. DE LA FUENTE.

a A. GARCIA-BAQUERO, Libro y cultura burguesa en Cádiz. La biblioteca de Sebastián Martínez, Cádiz, 1988. 
de reflexión sobre las relaciones entre burguesía keconómica y burguresía *intelectuals negocios y cultura.

Un capítulo de singular importancia era el de los funcionarios, investigado por la modema historia social de la Administración ${ }^{82}$. En una de sus conocidas obras, Domínguez Ortiz se pregunta: «Los funcionarios civiles, y prinmpalmente, los de Hacienda, żon o no burgueses?». Y responde: «Poseen rasgos burgueses, pero su dedicación profesional, su dependencia, su conformismo, al menos externo, sus limitados horizontes no armonizan con el tipo burgués puro» ${ }^{88}$.

En Espana la adscripción a las diversas ramas de la Administración -central, tenitorial o local-creaba situaciones muy distintas. Y no era la misma tampoco la posición de los funcionarios de Hacienda o de Justicia.

En el plano profesional, como advierte González Enciso, ahay que distinguir entre los universitarios y los que no lo son; los que cumplen funciones directivas en los distintos organismos y siguen una carrera funcionarial y losi oficiales de rango inferior, cuya función munca es directiva». "La magistratrura, la carrera de las leyes en audiencias y chancillerías era casi el único camino hacia los Gonsejos. Algumas Secretarias -Gracia y Justicia, Guerra, por ejemplotenían una composición en sus escalones más prestigiosa socialmente que otras de carácter mảs tácrico, como pulieran ser todas las ramas de rentas reales de la Secretaría de Hacienda. Estas diferencias de prestigio llevaron a unos y outros a acentuar su espíritu corporativo, a defender sus intereses frente a los demás y a tratar de conseguir exenciones y honores que les dieran un toque de distinción».

¿A qué sectores sociales pertenecían los funcionarios? La cuestión es discutida y discutible. Muchos de los altos cargos se reservaban a la nobleza o eran un medio para emoblecerse. Aunque bastantes funcionarios procedían origimariamente de la burguesía, con el paso del tiempo y al avanzar en su canrera, se convertian en nobleza nueva. Los cargas eran ocupados, frecuentemente, por colegiales, hijos de aristócratas formados en los Colegios Mayores, Fin un plano más bajo se sitúan los que, «sin llegar a las esferas más altas, formaron el

3? P. MOLAS Y OTROS: Historia social te La Administración española. Estudias yulnu has siglos XVI y XHH, Barcelona, 1980. También, L. M. ENCISO, „Pedro Molas y la Historia social de li Administración, en P. MOLAS, Consejos y Audiencias durante et reinado de Felipe $\|$. Vallowidid, 1984, págs. 7-77.

* A. DOMINGUEZ ORTIZ, Sociedad y Éstado en la España del s. XWH, pág. 183.

3" A. GONZÁLEZ ENCISO: "Los habitantes de las ciudades: la burguesía, en L. M. FN(ISO, A. GONZÁl.EZ ENCISO, T. EGIDO, M. BARRIO, R. TORRES, Los Borthones en et a XWI (1700-1.908), Madrid, 1991, págs. 89-90. 
núcleo fundamental del funcionariado», opuesto a los altos cargos y acerbos en su crítica a la aristocracia. «Se trata de individuos que se han formado en las Universidades, pero fuera del clan aristocrático. Son los golillas, que se enfrentaron sistemáticamente a los colegiales». Muchos eran hidalgos, y, «si hay que llamarlos burgueses, lo son en el sentido tradicional de la palabra». ${ }^{90}$ En ciertas Audiencias, a partir de 1765, "no sólo dejaron de nombrarse de forma prioritaria colegiales mayores, sino personas vinculadas a la institución universitaria. En cambio, se prefirió a los «abogados - son los casos de Roda, Campomanes, Moñino o Lanz de Casafonda» y a «hombres procedentes de la administración local, corregidores de letras y alcaldes mayores». ${ }^{91}$ Particular relieve alcanzó la Academia de jurisprudencia de Santa Bárbara, de Madrid, semillero de "manteístas para las carreras de atoga» y de "varas".

En cuanto a los funcionarios de rango menor, difícilmente pueden ser ubicados en la burguesía. En los sucesivos ascensos de los burgueses -comerciantes, negociantes, industriales, universitarios o profesionales- las influencias y relaciones interpersonales tenían una importancia decisiva. En tales relaciones y en la órbita política el clientelismo -por ejemplo, las clientelas navarras o vascas, el "partido español», los «colegiales», los «golillas»estaban a la orden del día. ${ }^{93}$

\section{La presencia y la actividad de los burgueses en las Sociedades}

Y, volviendo al hilo fundamental de nuestra exposición, ¿̨cómo interpreta la historiografía actual el papel de la burguesía en las Sociedades? Sin ánimo de ser exhaustivos, concedamos atención a trabajos significativos aparecidos en los últimos años.

a) Las fuentes para el estudio sociográfico de las Económicas.

Los primeros análisis sobre estructura social de las Económicas se habían hecho sobre la base de los catálogos o listas de socios publicados por las propias entidades. Ese procedimiento fue usado, en fecha temprana, por Francisco Aguilar Piñal para la Sevillana ${ }^{94}$-en la que tuvieron preeminencia los nobles-,

* A. GONZÁlEZ ENCISO, Ibid.

21 P. MOLAS: La Monarquía Española (Siglos XVI-XVIII), Madrid, 1990, págs. 145-146.

92 A. RISCO: La Real Academia de Santa Bárbara de Madrid, Toulouse, 1979.

93 A. GONZÁLEZ ENCISO, Ibid.

^ F. AGUILAR PIÑAL, aLa Sociedad Económica de Sevilla en el s. XVIII ante el problema docente», en Las Reales Sociedades Económicos de Amigos del País y su obra. Comunicaciones pre- 
por J. M. Caso para la Económica de Asturid - dominada por eclesiástion y nobles-: «a Junta Directiva estuvo compuesta por eclesiásticos y nobles. Fin la linta de socios de las primeros años, gue en buena parte he legrado reconstruir, hay algún tomerciante, pero no paree que su presencia baya supuesto nada en la vida de la Sociedad en sus inicios y E Emest Lluch para las Sociedades de Tárrega, Tarragona, Lérida y Gerona, donde el papel esencial correspondió a terratenientes y clérigos. ${ }^{95}$ Por 51 parte, Carlos Corona, en un artículo sobre la Sociedad de Jaca, esbozó un apunte de distribución de los socios por grupos sociales y dejó constancia de la nutrida presencia de clérigos en la entidad.

Tiempo después, J. F. Forniés manejó tambiên las listas de socios de la Aragonesa, pero formuló críticas respecto a su plena validez, "Los porcentajes fijados para cada estamento social en los catálogos de socios», escribía Formiés, * bedecen al uomento preciso de creación de las Sociedades, y se dio el caso de que gran parte de los inscritos jamás concurrieron a las mismas, ni con su presencia física, ni con su contribución económica». No obstante, concluía, tales «estudios son útiles cuando la documentación de la Sociedad en concreto ha desaparecido total o parcialmentes.?

No han sido éstas las únicas prevenciunes subre las listas de socios. Algunos autores insisten en que en ellas se ocultan, o no se expresan, datos sobre determinados socios, ${ }^{98}$ Asimismo se ha hecho observar que muchos de los afilia-

sentadas en el Pleno de fa Asamblea celebrada en Sen Sebastian los clias 9 al 11 de diciembre de

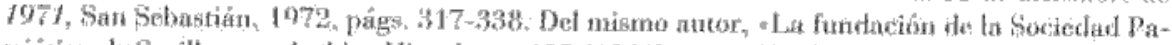

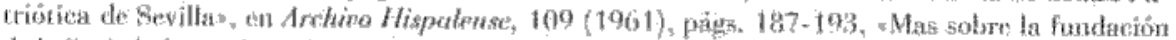

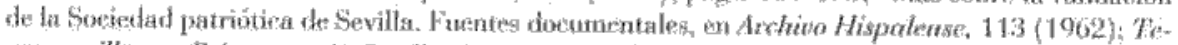
mas semillanes. Primera serie, Sevilla, 1972, paigs. 123-140.

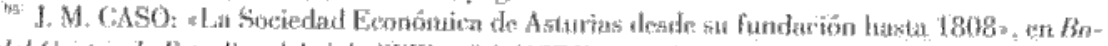

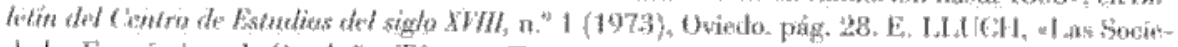

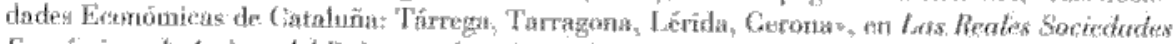

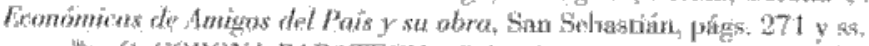

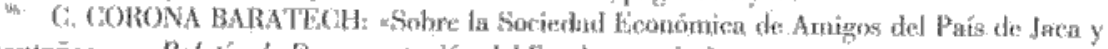

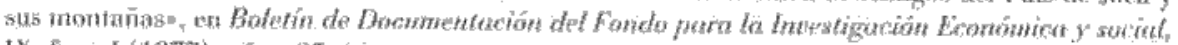

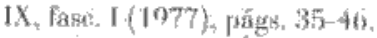

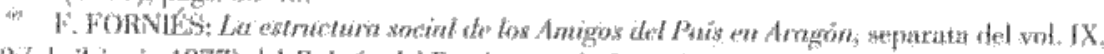

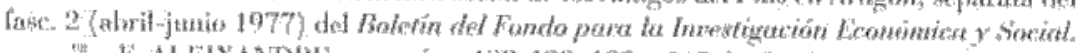

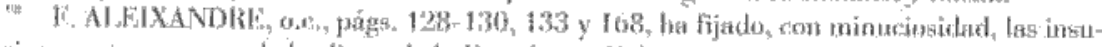

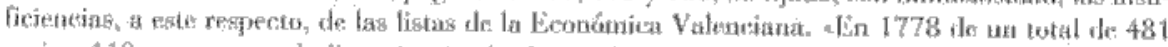
socios, 110 aparecen en la lista sin ningún dalo más que su nombre; en 1788, de 216 hay 43 sin identificar; en 1791, de 182, 39; en 1794, de 170, 37; en 1796, de 194, 42; en 1797, de 203, 39; en 1799, de 167, 30; ten 1800, de 108, 67

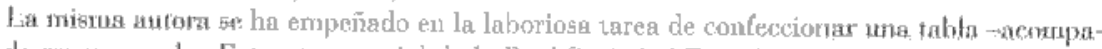

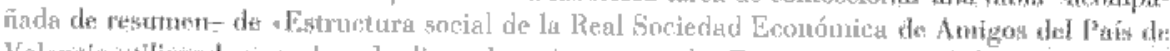

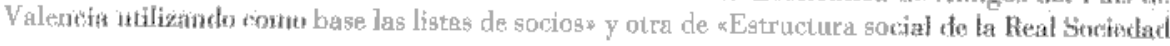


dos que figuran en las listas no participaron lo bastante $-y$, a veces, nada- en las actividades de la Sociedad, y no pagaron sus cuotas ni hicieron aportaciones económicas extraordinarias." Es posible que las listas sirvieran de escaparate para acreditar la importancia de ciertos socios, a los que, de paso, se podía halagar al hacer públicos sus nombres, y atraer, con el señuelo de la presencia de prohombres, a otras gentes, pero no se puede ignorar ${ }^{100}$ que existió también un deseo de informar, acorde con el propósito de la Administración y la mentalidad de época. Ello explica que, entre los nombres registrados, algunos tuvieran escaso relieve o notoriedad.

En conjunto, las listas son imprescindibles cuando, o no existe otra documentación, está muy dispersa o resulta de difícil localización. Parece exagerado, por tanto, habłar, como ha hecho J. L. Castellano, de la «poca, prácticamente nula, importancia de las listas de $\operatorname{socios}{ }^{101}$ y no es atinado considerarlas fuentes inútiles.

Sin embargo, las listas, o no sirven para identificar a todos los socios, o no resultan útiles para analizar una larga secuencia temporal. ¿Qué hacer entonces?

La primera respuesta, y tal vez la más esclarecedora, nos la proporciona la documentación de las propias entidades, si existe. En la mayor parte de casos. serán los libros de actas, donde se da cuenta de las reuniones de las Juntas ordinarias o extraordinarias de la Sociedad y, con frecuencia, «se deja constancia de la admisión de nuevos socios y de la sección en que fueron admitidos". ${ }^{102}$ Otras veces se han usado los libros de resoluciones de la entidad, como hizo Forniés para la Aragonesa. ${ }^{103}$ Cuando las circunstancias lo acon-

Feomónica de Amigos del País de Valencia tras la identificteión de socios cuya profesión no se

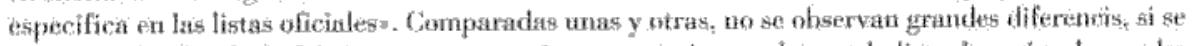
exomptüa el epigrafe de fabricantes y comerciantes, uny incompleto en la lista de socios, to gue ha "xigido a la Dra. Alcixandse una rabajosa búsqueda en fuentes eomplementarias.

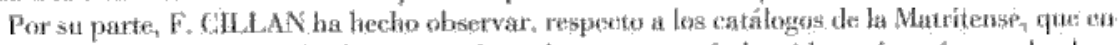

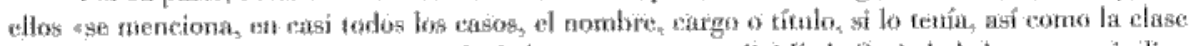
de socio y la sechion a la que pertenceía de las tres eu que se dividia la Sociedach A veces, se indira et lugar de residencia y otras tircunstancias de interés. En pocas ocasiones. Las referencias anon

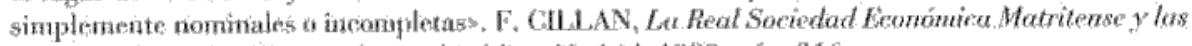
reformes de Cartes III, iesis dectoral inédita, Madrid, 1900 prág. 316.

w. M. VELÁZQUE7, 0.4. pág. 198.

100 F. ALEIXANDRE, o. c., pág. 127.

101 J. L. CASTELLANO, Luces y reformusmo, pág. 180.

102 F. CIILLÁN OTERO: La Sociedud Económica Matritense, pág. 212 y ss. otros muchos estudiosos se han servido de este tipo de documentación.

10-4 J. F. FORNIFS: La estructura social de los Amigos del País en Aragón, pág. 4, nota 22. 
sejan, puede ser útil asimismo el manejo de actas de comisiones o juntas particulares, aunque no proporrionan, por lo común, índices de asistencia y tienen otras carencias. ${ }^{104}$

Se ha acudido, y debe acudirse, igualmente a más fuentes documentales. Por citar obras recientes, invoquemos el ejemplo de F. Aleixandre, cuyas búsquedas para completar la ascendencia social y profesional de los Amigos del País de Valencia ha sido particularmente minuciosa. La investigadora valenciana usó documentos de los Archivos de Simancas-singularmente, del Consejo Supremo de Hacienda y de la Junta de Comercio y Moneda-e Histórico Nacional -sección de Consejos-, Archivo del Reino de Valencia, de la Universidad de Valenria y de la Sociedad Económica Matritense. ${ }^{105}$ Otro autor de los años 80, Matías Velázquez, ${ }^{106}$ se ha servido, para su tesis doctoral, de los «Expedientes de comprobación y rectificación de los datos y valores declarados en el Catastro de Ensenada» y en las "Respuestas generales», contenidos en Simancas y promovidos por la Junta de Énica Contribución entre 1760 y 1764. El historiador murciano ha usado asimismo los Libros -relativos a Murcia- correspondientes al nuevo proyecto de Contribución. Unica, depositados en el Archivo Histórico Provincial de Murcia, y otros papeles del Archivo Histórico Nacional -singularmente, de Consejos suprimidos-, Archivo de la Sociedad Económica Matritense, el de Campomanes, el Municipal de Murcia, la Real Academia de la Historia, el catedralicio y el diocesano de Murcia y municipales de Mula, Cieza, Tutana y Cehegín. Otros varios investigadores han utilizado documentación procedente de Archivos Provinciales. Municipales o Universitarios ${ }^{107}$.

Valor complementario, pero no desdeñable, tienen los periódicos de la época, poco utilizados para este tema. Menos significativos son los datos proporcionados por los viajeros y otras fuentes menores.

A todo ello hay que añadir la rica serie de fuentes impresas, de las que se da noticia en diversas publicaciones citadas, o las obras instrumentales de ar-

10+ F. CILLÁN: La sociedarl Eomóntía Mutritense, pág. 317.

105 F. Al_EIXANDRE, o.c, expecialmente, págs. 503-50.5.

106. M. VELÁZQUEZ, 0.0., especialniente, pág. 194-195 y 299-303.

107 Acúdase, por citar trabajos de interés, a las obras de G. DEMERSON:-La Sociedad Económica de Amigos del País de Avila (1786-1857), Ávila, 1968-; R. M. GONZÁLEZ, La Sociedad Económica de Amigos del País cte León, León, 1981; N. RUPEREZ, La Saciedad Eronómica de Amigos del País de Sorta (1777-1809). Estudio Institucional, Soria, 1987 ; F. BALLESTEROS, La Sociedad Económica de Amigos del Pás de Bus'gos, Burgos, 1983 y J. L. CASTELLANO, Luces y reformismo. Las Sociedades Económicas de Amigos del Pais del Reino de Granada en el $s$. XWH, Granada, 1984. 
chiveros, documentalistas o bibliotecarios. De los estudios sobre Sociedades, ya abundantes, y de otras publicaciones de temas concomitantes pueden obtenerse también referencias útiles.

\section{b) La Sociedad Económica Matritense}

En teoría, la Económica matritense debía atraer a todos los sectores sociales, y particularmente, a la burguesía. ¿̨Fue esto así? Fernando Cillán, que ha prestado singular atención, en su tesis doctoral, a la sociografía y, en general, al estudio institucional de la Sociedad, nos ha dado argumentos para responder a la pregunta.

Para empezar, ha precisado la cuantía y clases de los socios. He aquí sus datos en relación con fechas significativas que nos interesan:

Cuadro III. Número de socios de la Matritense

\begin{tabular}{lccccc}
\hline & Numerarios & Agregados & Correspondientes & Mérito & Total \\
\hline $\mathbf{1 7 7 5}$ & 176 & 7 & 0 & 1 & 185 \\
$\mathbf{1 7 8 5}$ & 424 & 23 & 1 & 24 & 468 \\
$\mathbf{1 7 8 8}$ & 437 & 26 & 1 & 25 & 489 \\
\hline
\end{tabular}

Fuente: F. Cillán, La Sociedad Económica Matritense..., págs. 214.

Cillán, como diversos autores respecto a otras sociedades, se preocupa por explicar la presencia y la colaboración de los diferentes grupos sociales en las tareas de la Matritense.

Las nobles no tuvieron una gran representación en el primer año, en el que ocupaban el tercer lugar en cuanto a número de socios -un $16,7 \%$ - por detrás del clero y de los comerciantes. Desde 1780 pasan a ser el segundo grupo más numeroso, y así se mantienen hasta 1788 , en cuya fecha suman el 13,2\% de los socios. ${ }^{108}$

En cuanto al clero, tuvo poca importancia en los orígenes de la Sociedad, pero, desde 1776, se implicó de forma cada vez más clara. A fines de ese año, eran 46 los socios eclesiásticos y doce años después, 65, lo que equivalía a un $12,2 \%$ del total de socios. ${ }^{109}$

F. CILLÁN: o.c., págs. 318-331.

F. CILLÁN: o.c., págs. 331-355. 
Los sectores burgueses o filoburgueses compusieron un conjunto numéricamente muy importante en Madrid.

Aunque la identificación de socios pertenecientes a la «burguesía económica» no es siempre fácil porque ciertos individuos, aún participando en actividades mercantiles o industriales, pertenecían a otros grupos, Cillán porie de relieve que «la Matritense puso especial empeño en la incorporación de miembros del comercio*. ${ }^{16}$ En enero de 1776 había ya 33 socios del sector *económico* -lo que equivale al $17,8 \%$ del total-, de los cuales 29 comerciantes -comerciantes y artesanos- tres diputados de los Cinco Gremios y uno, maquinista. Los comerciantes crecicron en número, pero los artesanos -grabadores, maquiniśta, telojerns, jardinero de S. M.-, no. Bien visto, poco tenían que ver estus últimos con la burguesía.

El detalle de la evolución cuantitativa del sector, posterior a 1775, según Cillán, es como sigue:

Cuadro $\mathrm{W}$.

Evolución de la burguesía "económica" en la Matritense después de 1775

\begin{tabular}{ccccc}
\hline & $\begin{array}{c}\text { Comerciantes } \\
1776\end{array}$ & Diputados Gremios & Artesanos & $\begin{array}{c}\text { Porcentaje respecto } \\
\text { al total }\end{array}$ \\
\hline 1785 & 42 & 3 & 3 & - \\
1788 & 43 & 3 & 8 & $11,2 \%$ \\
\hline
\end{tabular}

Fuente: F. Cillán, o, c., págs. 373 y 378.

El grupo más numeroso, como cabía esperar en la Matritense, era el de los funcionarios. Del conjunto de niembros de la Sociedad, en los comienzos pertenecian a este grupo 52 personas - un $34 \%$ del total-, y su presencia subió luego de forma rotunda.

La variedad de cargos era notable. Había secretarios de Estado-Indias y Hacienda-, un gobernador y miembros de los Consejos -de Castilla, de Indias, de Hacienda, de Guerra, de Inquisición-, fiscales del Consejo de Castilla, secretarios de diversos Consejos -Ordenes, Guerra, Castilla- y de la Comisaría General de Cruzada-, secretarios de otros altos organismos -de la Cámara de Castilla, de la Comisaría de Cruzada, del Secreto del Santo Tribunal de la Inquisición-, abogados de los Reales Consejos, directores generales -de Correos,

in F. CILILÁN: o.c., pág. 374. 
de las Rentas de Tabacos, Alcabalas, Aguardiente y Naipes, del Banco de San Carlos-, el procurador general de Concejo de La Mesta, un visitador general de Montes y plantíos, un tesorero general, directores de fábricas, compañías o laboratorios - de la fábrica de curtidos de Caracas, de la fábrica de sedas de Granada, de la fábrica de Valencia, del laboratorio de bronces, de tintes de las fábricas de Barcelona o las de algodón y lino-, relatores del Consejo de Castilla, escribanos de Cámara del Consejo de Castilla, miembros de la Junta de Comercio de Barcelona, oidores de varias Audiencias, un intendente, corregidores, alcaldes mayores, alcaldes de Casa y Corte, regidores de diversos ayuntamientos, el registrador de sisas de Madrid, escribanos de Ayuntamiento, otros cargos menores y oficiales mayores u oficiales de diversas Secretarías. Los más numerosos eran los miembros de los Consejos (26), seguidos de los abogados de los Consejos y de los oficiales. De esta turbamulta de personajes de la Administración central, territorial y local, de Justicia o de otros departamentos, a algunos cabe situarlos más bien en la nobleza y a otros -singularmente, los oficiales-, en la mesocracia, pero no pocos debían de tener concomitancia con la burguesía.

La evolución cuantitativa de este notable grupo, a partir de 1776 , fue la siguiente:

Cuadro V. Funcionarios y oficiales en la Matritense

\begin{tabular}{ccc}
\hline & $\begin{array}{c}\text { Funcionarios y } \\
\text { oficiales }\end{array}$ & $\begin{array}{c}\text { Porcentaje respecto al } \\
\text { total de socios }\end{array}$ \\
\hline 1775 & 52 & $34 \%$ \\
1785 & 140 & $27,5 \%$ \\
1788 & 142 & $28 \%$ \\
\hline
\end{tabular}

Fuente: F. Cillán, o. c, págs. 363.

Menos relevante fue la presencia de militares. En 1775 había 6 -un 3,2\% del total de socios-, 25 en 1785 y en 1788,2 -un $5,1 \%$ del total de socios-. Eran capitanes generales, coroneles, intendentes, jefes y oficiales, contadores, suboficiales y miembros de la clase de tropa. Pocos de ellos pueden enmarcarse en contornos burgueses.

Más próximos a la burguesía estaban algunos de los profesionales que participaron en la Matritense.

A lo largo de los años analizados, colaboraron con la entidad sólo 25 personas procedentes de medios intelectuales -un $5,8 \%$ del total de socios-. La 
mayor parte eran académicos - de la Historia, de San Fernando, de La Española, de La Academia de Buenas Letras de Sevilla-, catedráticos o profesores -de los Reales Estudios de San Isidro, del Jardín Botánico, del Seminario de Nobles-, colegiales mayores - del Arzobispo de Salamanca, del de Cuenca de Salamanca-. En las listas figuran también un secretario de interpretación de lenguas, un escultor y un pensionado para estudiar Química. Es difícil precisar quienes eran burgueses y quienes mesócratas.

Lo mismo sucede con el reducido grupo de profesionales liberales. En 1776 sumaban 5 -un 1,6\% del total-, aumentados hasta 10 nueve años después, y hasta 11 , en 1788 -un $2 \%$ del total-. Entre ellos, había abogados, un arquitecto, un ingeniero hidráulico, un médico, un pintor anatómico del Real Gabinete de Historia Natural, un pintor de Cámara y un licenciado.

Todo este complejo amasijo de burgueses y gentes de las clases medias, ¿se comprometieron poco o mucho en las tareas de la Sociedad? Para dar respuesta a la pregunta Cillán rastrea la asistencia de socios a las juntas o comisiones.

Para empezar, Cillán"1 puntualiza que, de 489 miembros de la Sociedad, sólo 57 (un 11,1\%) asistieron a un número de juntas superior al $10 \%$ del total de las mismas. En consonancia con ello, el detalle del número de Juntas por año y la asistenciáa a las reuniones es como sigue:

Cuadro V. Juntas y asistencias en la Matritense

\begin{tabular}{lccc}
\hline & N. ${ }^{\circ}$ juntas & N. ${ }^{\circ}$ asistentes & Porcentaje \\
\hline 1777 & 48 & 26 & $8,9 \%$ \\
1780 & 50 & 20 & $5,5 \%$ \\
1785 & 53 & 23 & $4,9 \%$ \\
1788 & 52 & 13 & $2,6 \%$ \\
\hline
\end{tabular}

No todos los sectores de socios de la Sociedad se comprometieron de la misma manera.

La asiduidad de los comerciantes e industriales en las actividades societarias fue relativamente elevada. Como sabemos, el número de inscritos suponía un $17,8 \%$ del total de socios en la etapa inicial, y luego, descendió al 13,3\% (1780) y al $11,4 \%$ (1788). Los porcentajes de asistencia a las juntas alcanzaron un $17,2 \%$ del total de asistencia de socios en 1776 , y después, el $18 \%$ $(1780)$, el $14,7 \%(1786)$ y el $14,5 \%(1788)$.

11 F. CILLAN: 0.c, pág. 323. 
Más intensidad tuvo la colaboración de los funcionarios. Si entre los inscritos sumaban un $34 \%$, en 1775 , y más tarde, el $29,6 \%(1780)$ y el $28 \%$ (1788), la participación -respecto al total de socios asistentes-alcanzó niveles del orden del $37,3 \%(1785), 39 \%$ (1780), 31,1\% (1786) y $22,01 \%$ (1788).

Los profesionales de la enseñanza, cuyo porcentaje de inscritos respecto al total era del orden del $6,4 \%(1775)$, y más tarde, del 6,1\% (1780) y del 5,1\% (1788), se prodigaron en sus asistencias. Los porcentajes respectivos de las mismas fueron: el $6,3 \%(1786)$, el $9,9 \%$ (1780), el $5,1 \%(1786)$ y el $8,7 \%$ (1788). El resto de los profesionales alcanzaron un paupérrimo nivel de inscripciones $-1,6 \%(1775), 2,2 \%(1780)$ y $2,2 \%(1788)$ - y, sobre todo, de participación -1\%(1786), 0,09\% (1780), 2,1\% (1785), $0 \%(1786)$ y $0 \%$ (1788). Algo más alto fue el porcentaje de asistencias de los militares: 1,8\% (1786), $0.09 \%(1780), 6,3 \%(1786)$ y $8,2 \%$ (1788).

Todos estos datos, añadidos a los de la nobleza y el clero, cuyo detalle es innecesario, para nuestro propósito, nos hace ver que la élite dirigente de la Sociedad estuvo compuesta por los funcionarios, los comerciantes e industriales, los eclesiásticos y los nobles. Menor influjo tuvieron los profesionales.

\section{c) El espacio castellano-leonés}

En 1986 vio la luz mi artículo sobre «Las Sociedades Económicas castellano-leonesas. Apunte institucional y sociológico» ${ }^{112}$. En él formulé, basándome en las investigaciones de G. Demerson -a las que ya me he referido- R. González y N. Rupérez, algunas conclusiones de interés respecto al tema que nos ocupa.

En la Económica Leonesa colaboraron, durante el s. XVIII, la nobleza, el clero-secular y regular-, las autoridades civiles, eclesiásticas o militares-el corregidor, el obispo, el capitán de milicias provinciales y los representantes del municipio.

El panorama sociográfico cambió algo durante los primeros decenios del siglo XIX. La minoritaria nobleza leonesa participó masivamente entre 1818 y 1834. También lo hicieron muy diversos sectores del clero. Pero, además, la Sociedad Económica de León «no dejó de contar con el apoyo de los dos

112 L. M. ENCISO RECIO: «Las Sociedades Económicas cstellano-leonesas. Apunte institucional y sociológico*, en Perspectivas de la España Contemporánea. Estudios en homenaje al profesor $V$. Palacio Atard, Madrid, 1986, págs. 21-46. Reeditado, con leves rectificaciones, en Actas del I Congreso de Historia de Palencia, Palencia, 1989, III, págs, 569-597. 
sectores que protagonizaban actitudes más renovadoras: la burguesía y las clases medias. A más de los diputados a Cortes, la Administración colaboró activamente: autoridades y representantes del Ayuntamiento, del Gobierno Civil y de la Diputación, titulares o empleados de los tribunales de Justicia, oficiales de Rentas, diversos secretarios, escribanos, empleados de Correos. Otros núcleos de socios los constituían las profesiones liberales [abogados. médicos, farmácéuticos, arquitcetos, catedráticos, profesores y maestros, periodistas, ingenieros de montes, caminos o minas], los militares, agricultores y ganaderos, fabricantes [de curtidos, loza y barajas], comerciantes y artesanos ${ }^{11.3}$.

En conjunto, de un total de 117 socios en 1819 y 256 en 18944 la representación burguesa es minoritaria -si se exceptúan la Administración y las profesiones liberales- y, en algunos casos, de contornos poco definidos.

Las investigaciones de Rosa González ${ }^{114}$ permiten ofrecer los siguientes datos cuantitativos al respecto:

Cuadro VII. Grupos sociales en la leonesa

\begin{tabular}{lrr}
\hline & N." burgueses o afines & Porcentaje \\
\hline \multicolumn{1}{c}{1819} & & \\
Miembros de la Administración & 42 & $35,9 \%$ \\
Miembros de profesiones liberales & 24 & $20,51 \%$ \\
Militares & 7 & $5,9 \%$ \\
Propietarios de tierras & 7 & $5,9 \%$ \\
Comerciantes & 4 & $3,4 \%$ \\
Fabricantes & 2 & $1,7 \%$ \\
$\quad 1834$ & & \\
Miembros de la Administración & 77 & $30,07 \%$ \\
Miembros de profesiones liberales & 32 & $12,5 \%$ \\
Militares & 18 & $7 \%$ \\
Propietarios & 19 & $7,4 \%$ \\
Comerciantes & 10 & $3,9 \%$ \\
Fabricantes & 5 & $1,9 \%$ \\
\hline
\end{tabular}

11 L. M. ENCISO: ¿Las Sociedades Ecomómicas castellano-leunesas ? pág. 584.

" R. GONZÁLEZ: La Real Sociedad Económica de Amigos del Pás de León, León, 1981, págs. 163-164. 
La adscripción a la Sociedad -e incluso el pago de cuotas- no eran suficientemente significativos, puesto que, como han puesto de relieve muchos autores, no comportaban un verdadero compromiso con las tareas societarias. Si se tiene en cuenta la asistencia a las juntas, «los más activos fueron los socios vinculados a la Administración, los profesionales y los propietarios, mientras que el clero y los nobles se mostraron menos diligentes, y los artesanos, declaradamente pasivos». ${ }^{115}$

Un caso peculiar es el de la Económica Numantina, ejemplarmente analizado por N. Rupérez. ${ }^{116}$ Entre 1777 y 1808 , se afiliaron a la Sociedad de Soria un total de 432 personas - de los cuales 206 vivían en Soria- y muchas de ellas pertenecían a la mesocracia o a la burguesía. ${ }^{17}$

La nobleza tuvo una participación minoritaria y tardía. Muy otro fue el caso del clero - ampliamente representado en la Sociedad- y de los sectores mesócratas y burgueses.

Mercaderes y artesanos venían a sumar el 40,6\% del conjunto de socios.

De los primeros, 20, es decir, los que vivían en la ciudad -un 9,7\% del total de socios "sorianos"- eran comerciantes al por menor, y sólo en dudosa medida puede clasificárseles de burgueses. Otros 74 eran "provinciales", 24 «regnícolas» y 22 seneméritos». Buena parte de los hombres del comercio residían en Cádiz - sede de una Junta Económica de la Sociedad Soriana- y se dedicaba al comercio al por mayor, fundamentalmente, con las Indias.

También tuvo amplia presencia en la Sociedad la mesocracia de artesanos y fabricantes de tono menor, con domicilio en la ciudad. En 1777 los 32 socios "sorianos» de esta especie sumaban el $31,8 \%$ de los socios «sorianos», pero en 1808 se habían reducido al 18,8\%. En cuanto a los artesanos de la provincia, eran pocos y de condición más modesta.

Al igual que en otras Sociedades del contorno castellano-leonés, los funcionarios de la Administración territorial y local -en su mayoría, residentes en Soria- se vincularon, en alto porcentaje, a la Económica Numantina. N. Rupérez estima que sumaban un 12,6\% de los socios, pero advierte que esta cifra debe aumentarse porque algunos funcionarios figuran en las listas con otro cargo u oficio, dada la duplicidad de tareas que realizaban. "Los más eran abogados

115 L. M. ENCISO: art. cit., pág. 585.

11. NIEVES RUPÉREZ: La Sociedad Económica de Soria. Estudio institucional, Soria, 1987.

1 L. M. ENCISO: art. cit., pág. 588. 
de los Reales Consejos, escribanos, funcionarios de la Contaduría provineial, administradores de la Renta de Tabaco, la lotería o las salinas, y miembros de los ayuntamientos de Soria y su provincia. En términos porcentuales los miembros de la Administración territorial o local sumaban, en 1777, 34 «sorianos», 5 «provinciales», 6 « regnicolas», 7 «honorarioss y 2 «beneméritos*,

En cuanto a los profesiones liberales, inicialmente representadas por un $1,08 \%$ de los socios, llegaron a totalizar, en 1808, un 12,2\% del total. Entre ellos, había, ante todo, médicos y boticarios y, además, arquitectos, abogados, un cirujano, maestros de latinidad o de primeras letras y catedráticos de la Universidad del Burgo de Osma. Los porcentujes eran de 19 «sorianos», 10 "provinciales» y 3 «beneméritos».

Para terminar, digamos que los militares y los hacendados alcanzaron escasa representación entre los socios. De los 10 militares, 3 eran «sorianos", 3 «prnvineiales » y 4 "regnícolas», y de los propietarios agrícolas, 4 егаn "sorianos» y 2 "provinciales».

El recuento de socios, por preciso que sed, no expresa la imagen viva de la Socicdad. Para acercarse al ella, se hace necesario matizar el grado de compromiso de los asociados en las actividades sucietarias. Una forma elemental de participación era la asistencia a las juntas generales. "Por lo que sabemos, fue a menos a lo largo del siglo. A la junta de constitución asistió el $74 \%$ de los socios. En 1785 sólo estaban presentes en las juntas generales, cl 24,7 \%, y en 1790 , cl $6,6 \%$. Los responsables de la organización llegaron a pensar que se: redujera el número de socios efectivos a un núcleo pequeño $-21-$, y el resto pasaran a ser supernumerarios». ${ }^{118}$

Algo más reconfortante era la asistencia a las sesiones de los órganos de dirección de la Sociedad. En ellas los sectores más activos fueron el clero, los funcionarios y -en menor medida- los comerciantes. Sin embargo, como hace observar N. Rupérez, si se relaciona el número de miembros sorianos de cada grupo -es decir, los que tenían capacidad para acceder a los «oficios" - con la cifra de los que desempeñaron cargos y el tiempo que permanecieron en ellos, se llega a la conclusión de que, en términus generales, la influencia de los nobles y de los propietarios fue grande. En contraste con ello, cabe subrayar que los artesanos, pese a ser numerosos los socios sorianos pertenecientes a este grupo, tuvieron una participación mínima en las tareas directivas.

11 L. M. ENCISO: ant. cit., pág. 591. 
En conjunto, quienes parecieron dar el tono en la Sociedad de Soria, pese a que unos pocos nobles y propietarios o algunos clérigos colaboraran en las tareas regeneradoras fueron tres sectores: la mesocracia-comerciantes al por menor, artesanos distinguidos, cargos menores de la Administración y del Ejército, ciertos profesionales-, la burguesía -comerciantes al por mayor, funcionarios de más relieve, profesionales de alguna nota-y el clero. No es éste el panorama que ofrecen otras Económicas castellano-leonesas.

Los datos que proporcionó en su día Demerson y la ampliación de los mismos que me ha sido posible realizar en fecha reciente permiten ofrecer un perfil sociográfico suficientemente expresivo de la Sociedad Económica Vallisoletana en $1785 .^{119}$

El número total de socios era de 181. La mayor parte de los miembros -141- eran socios numerarios, y el resto, honorarios -16-, correspondientes -19- y de mérito -5-. A ellos se agregaban seis alumnos, categoría propia de Valladolid y de otras Sociedades.

De los 16 honorarios, 11 eran nobles y dos añadían, a la condición de aristócratas, la de consejeros de Castilla. Los demás eran eclesiásticos $-2-$ y altos funcionarios -un presidente de la Chancillería y dos miembros del Consejo de Castilla.

Los de mérito no tenían tanto relieve social. Dos desempeñaban cargos de la Administración municipal, uno era miembro de Academia, uno fabricante y otro, no identificado.

Entre los correspondientes había tres nobles, un eclesiástico, tres funcionarios, un militar y un profesional. Estos y todos los demás correspondientes eran miembros, o fundadores, de otras Económicas.

En cuanto a los «alumnos», eran profesores universitarios de tres especialidades: Derecho, Filosofía y Matemáticas.

Con ser interesantes los datos que llevamos expuestos, mayor interés posee la recomposición del espectro social y profesional de los numerarios.

Diecisiete miembros de esta última categoría pertenecían a la nobleza -un $12 \%$ del total-y 47 al clero -es decir, un $33,3 \%$ del total.

Pero la burguesía debió de desempeñar también un papel de cierto relieve en la Económica Vallisoletana.

119 L. M. ENCISO: «La génesis de la Real Sociedad Económica de Valladolid. Nuevos datos», en Homenaje a los profesores Jover-Zamora y Palacio Atard, Madrid, 1990, t. II, págs. 13-38. 
De los socios numerarios, 9 -o sea, el 6,6 \% del total- pertenecían a la burguesía mercantil. Otros 32 -algo más del $22 \%$ del total de socios- pueden filiarse, con ciertas reservas, en la eburguesía intelectual». Eran altos cargos de la Chancillería -12-, ocho de los cuales pertenecían, además, al Cionsejo de S. M.; un inquisidor, un contador general, nueve catedráticos de Universidad, tres delegados de servicios de la Administración Central en Valladolid y su provincia, dos corregidores, tres regidores perpetuos, un procurador general de Valladolid y un profesional liberal.

Es dudoso si deben situarse en la burguesía o en la mesocracia siete cargos más de la Chancillería, seis funcionarios medios de delegaciones de la Administración contral, dos diputados del Común, un alcalde mayor de Rueda, tres militares, siete profesores universitarios, cinco colegiales y diversos miembros de Sociedades o Academias.

En conjunto, si nos atenemos a la época fundacional, los núcleos sociales y profesionales predominantes en la Vallisoletana fueron los clérigos, los nobles, los funcionarios civiles, los universitarios, los académicos y los comerciantes. Si se compara con otras Sociedades del entorno castellano-leonés, se puede comprobar que los socios de la Económica de Valladolid eran más y inás cualificados que los de otras, si se exceptúa, quizá, la de Segovia. ${ }^{120}$

¿Se mantuvo este panorama en los años siguientes? Carecenus de información suficiente para afirmarlo. Y tampoco nos es dado medir el grado de participación de los socios en las actividades societarias, piedra de toque, como venimos afirmando, para reconstruir la vida de la entidad.

La Económica de Zamora es un ejemplo de institución promovida desde el poder y con escasa vida propia. ${ }^{121}$ En consonancia con ello, las modestas iniciativas que afrontó eran dictadas por una élite de cclesiásticos y funcionarios de las órbitas central -pocos-, territorial o local.

La lista de fundadores, único instrumento de que se dispone de momento. nos hace ver que el número de socios -en 1778-era de 88. De ellos, sólo se han identificado, hasta ahora, 67 .

La representación nobiliaria era menguada, incluso si se tiene en cuenta que algunos militares distinguidos, que no figuraban como tales, fuesen nobles.

220 L. M. ENCISO: *La génesis de la Real Sociedad Éconómica de Valladolid. Nuevos datos* pág. 37.

121 L. M. ENCISO: aLa génesis de la Sociedad Econónica de Anigos del País de Zamora*, en Estudis, 14 (1989), págs. 219-244. 
En cambio, los eclesiásticos, comparativamente, eran muchos: 24. La burguesía urbana, o «rural», era escasa y, en general, poco cualificada.

Entre los socios había 2 comerciantes 1 fabricante, 12 funcionarios civiles -desde el administrador de Rentas provinciales a regidores e incluso escribanos de la ciudad-, un ingeniero, 15 labradores -algunos labradores y ganaderos, otros sólo labradores y, posiblemente, con diversidad en los niveles de rentasy 11 militares -desde el capitán general a oficiales de la contaduría del Ejército o un teniente de las Reales Guardias-. Buena parte de ellos pertenecían más bien, como he escrito en otro lugar, a las clases medias. ${ }^{122}$

En fecha reciente, Antonio Meléndez Gayoso ha puesto punto final a su tesis doctoral, centrada en el estudio de la Real Sociedad Económica de Amigos del País de Segovia. El trabajo, de singular calado, se ha visto precedido por varios artículos del autor, entre ellos, uno dedicado a la "Sociografía de los Amigos del País de la Real Sociedad Económica de la provincia de Segovian. ${ }^{123}$

Meléndez ha precisado, con rigor, la evolución numérica de los socios y su distribución socioprofesional. He aquí el cuadro en que ambos extremos se resumen:

Cuadro VIII. Número de socios de la Segoviana y distribución socioprofesional por años

\begin{tabular}{lrrrrrrrr}
\hline & 1785 & $\%$ & 1785 & $\%$ & 1785 & $\%$ & 1785 & $\%$ \\
\hline Nobles & 24 & 20,6 & 23 & 24,2 & 22 & 25 & 13 & 17,1 \\
Eclesiásticos & 20 & 17,2 & 19 & 20 & 12 & 13,6 & 9 & 11,8 \\
Comerciantes & 5 & 4,3 & 5 & 5,2 & 3 & 3,4 & 2 & 2,6 \\
Fabricantes y artesanos & 16 & 13,7 & 14 & 14,7 & 15 & 17 & 16 & 21 \\
Agricultores & 1 & 0,8 & 2 & 2,1 & 1 & 1,1 & 1 & 1,3 \\
Administración y prof. & & & & & & & & \\
$\quad$ liberales & 29 & 25 & 21 & 22 & 25 & 28,4 & 23 & 30,2 \\
Sin clasificar & 15 & 12,9 & 7 & 7,3 & 3 & 3,4 & 7 & 9,2 \\
\hline & 116 & & 95 & & 88 & & 76 & \\
\hline
\end{tabular}

Fuente: A. Meléndez, «Sociografía de los Amigos del País de Segovia», pág. 843.

12 L. M. ENCISO págs. 239

123 A. MELÉNDEZ GAYOSO: «Sociografía de los Amigos del País de la Real Sociedad Económica de la provincia de Segovias, en Coloquio Internacionat sobre Carlos III y su sigto. Actas, Madrid, 1990, t. II, págs. 841-850. 
De estas cifras -en las que no se incluyen a los socios natos- se derivan algunas conclusiones esclarecedoras.

La primera se refiere al número de socios. La línea evolutiva, a lo largo del siglo XVIII, es a la baja. La mayor parte de ellos vivían en Segovia capital; otros, pocos, en Madrid, y aún menos en pueblos de la provincia y en Badajoz, Sevilla y Zaragoza.

Los fundadores fueron, principalmente, nobles, eclesiásticos y militares. Los miembros del estamento nobiliario tienden a descender, suavemente, en número e importancia relativa, en el serio de la Sociedad. Lo propio sucede, aunque más acusadamente, con los eclesiásticos,

El sector de mayor entidad numérica era el de los funcionarios de la Adninistración central o focul-sobre todo, abogados de los Reales Consejos, administxadores de Rentas provinciales, regidores-y los profesionales - profesores, licenciados, ayudantes de la Escuela de Dibujo- A medida que avance el sigho, si se exceptía el ario 1787 , tienden a aumentar en térmimos ahsolutos y en refación con el resto de los socios -25\% on 1785, $22 \%$ en $1787,28,4 \%$ en 1793 y $30,2 \%$ en 1799 -.

Un rasgo característico de Segovia es la nutrida presencia de fabricantes de paños -los Arraz de la Torre, los Tomé, Torres de Velasco y Laureano Ortiz de Paz-, varios de ellos ganados por la pasión nobiliaría. Su número se mantuvo igual con el tiempo, pero creció respecto al total de socios $-13,7 \%$ en 1785 , $14,7 \%$ en $1787,17 \%$ on 1793 y $21 \%$ en 1790 - El sector primario, como bien dice Meléndez, acarece de importancia, a pesar del predominio en Segovia de la producción agraria... y de la progresiva ruralización de la población que se experimentó en el siglo XVIII, ${ }^{124}$

En cuanto a los nilitares, entre los que el autor no incluye a los nobles que ocupaban cargos en el Ejército, eran pocos. Solían residir en Segovia, y los más, estaban vinculados a la Academía de Artillería.

De todos estos sectores, jcuáles fueron los encargados de orientar y dirigir las actividades de la Sociedad?

La media de asistencias a juntas de la entidad por socio, desde 1786 a 1804, según puntualiza Meléndez ${ }^{125}$ fue de 57,4. Si nos referimos a cada grupo, observaremos que «los militares son los que acuden con mayor asiduidad -99

\footnotetext{
22 A. MELÉNDEZ, «Sociografía», pág. 847.

125 A. MELÉNDEZ, "Sociografía», pág. 844.
} 
asistencias por persona-, seguidos de los clériges con 94 , mientras que mingmo de los agricultores de los que tenemos uoticis acudieron a ninguna junts y los nobles... apenas lo hicieron (4,6 asisteucias) \%. Otra forma posible de auscultar el nivel de participación cousiste en uedir la presencia de los grupos en las tareas directivas. «De 13 militares que fueron miembros de la Económica, 5 -o sea, el 10,6\% de los oficios-ocuparon cargos oficiales -el más importante de los cuales fue Alcalá Galiano-, mientras que sólo 3 fabricantes los ostentaron. La alta participación de los eclesiásticos es consecuencia de que fuerom los que más cargos disfrutaron.... Desempeñaron tambiên un buen número de cargos -10 , lo que equivale al $21 \%$ del total de cargos- los funcionarios, y menos, los nobles -6 , es decir, el $12,7 \%$ del total. En suma, la vida de la Sociedad dependió, en buena medida, de los eclesiásticos, los funcionarios, los fabricantes, comerciantes y profesionales y, pese a su pequeño número, de los militares. La nobleza se mostró más pasiva.

\section{d) Las Sociedades manchegas}

En los albores de los años 80, José María Barreda y Juan Manuel Carretero publicaron su interesante monografía sobre Ilustración y reforma en La Mancha. Las Reales Sociedades Económicas de Amigos del Paús.

Las dos Sociedades más importantes de este ámbito fueron las de Cuenca y Toledo, cuyos rasgos se asocian a las de otras pequeñas, o medias, ciudades de provincia. En Cuenca el número de socios, eu 1783, era de 105, camidad relativamente abultada que se explica «porque su primer director fue ol obispo, con lo cual se inscribieron en la Sociedad 52 eetesiásticos, entre ellos, todos los presbíteros, canónigos y demás dignidades de la catedral ". ${ }^{126}$ En Toledo los socios localizados por los autores eran sólo 47. Las demás Sociedades, típicamente rurales, contaron con pocos miembros: Yepes, 18; Yébenes, 19; San Clemente, 4 y Ocaña, 3 promotores y un número de socios no identificado.

La composición social de los institutos de Amigos del País en este ámbito

126 J. M. BARREDA FONTES-J. M. CARRETERO ZAMORA: Ilustración y reforma en La Mancha. Las Reales Sociedades Económicas de Amigos del País, Madrid, 1981, págs, 48 y 41. Véance asimismo: M. ESPADAS, "Ciudad lieal y su Sociedad Eeonómica de Amigos del Paíson en Cundernes de Estudios Manchegos, 4, 11 época; J. GARCIA FRAILE, La Gociediat Econcimica de Amiges del Pais de Sigüenza (1776-1805): notas y desarrollo historico, Madrid, 1986; Li HGLERIJELA, «Ta Real Sociedar Econóntica de Amigos del País de Alcázar de San Juans, en Boletin del

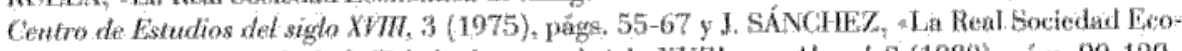
nónica de Arrigos del País de Toledo durante el siglo XVII =, en Almud, 20 (1980), págs. 99-129. 
depara pocas sorpresas. ${ }^{1.7}$ "Salvo en Cuenca, en cuya Sociedad figuraban como socios 5 señores de vasallos, en el resto de las Sociedades no consta que haya ningunon. ${ }^{128}$ Causa extrañeza la ausencia de títulos, particularmente rara en Toledo.

El estamento eclesiástico alcanzó una alta representación. En Cuenca, por la razón explicada, llegó a haber 52 clérigos y en Toledo, 6, en los primeros momentos, y más después, «cuando el director fue un canónigo». En las Socicdades rurales, la contribución de los pueblos parecía obligada, pero Barreda y Carretero sólo han identificado a 5 socios de este tipo en Yepes. El propio Ciarretero hace observar que, en los institutos de Amigos del País manchegos que no llegaron a tener actividad, se acusa una "presencia abrumadora del estamento eclesiásticon. ${ }^{129}$

Como era de prever, la burguesía dejó tibias huellas por estos pagos. En Cunca, en las listas se incluyen a 2 «abricantes de barraganes", 3 de la "Real Fábrica de tejidos de lana» y 2 miembros del «comercio de la ciudad». En Toledo, curiosamente, no hay referencias, aunque en los documentos figuran varios con propiedades rústicas y urbanas. ${ }^{13 n}$ Los labradores-generalmente poeo acomodados- y algmos hidalgos de Yepes, Yébenes y San Clemente nada tenían que ver con la aburguesía rural». Y tampoco los labradores de "mediano pasar» de las Sociedades proyectadas en Vara de Rey, Bogarra y Arbancón. "'.

Fn cuarito al funcionariado, ampliamente representado, tienc escasas connotaciones burguesas, "En Tuledo ajarecen seis regidores y en Cuenca tres; también figura un alcalde en cada una"; en San Clemente los promotores son el alcalde mayor y el corregidor de dicha villa: y en Yébenes, el alcalde mayor. Esta oligarquía, parte de la cual es asimilable a la segunda nobleza, basaba su "poder económico en las rentas de fincas urbanas y en censos y juros, y el político en el férreo control de los cargos municipales, [y] acude a las Sociedades Económicas con el ánimo de ocupar también ese nuevo espacio político abierto desde Madrid, de exclusivizarlo, evitando así que la ciudad tuviera otros portavoces ajenos a su grupo ante el Consejo y la Corte».

I27 Para una janorámira socieconómica de este espacio acudase a la momografía re BARREDA-CARRETERO, págs. 23-36, y a la excolente olite de J. LOPEZ SALAZAR, Esiructuras ugrartas y socipdad whrd en La Moncha, ss. XVI-XII, Ciudad IPeal, 1986.

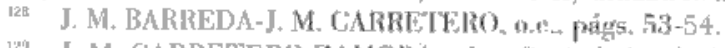

129 J. M. CARRETERO 7AMORA: I as Sociedaces de Antugos del País en La Mancha:

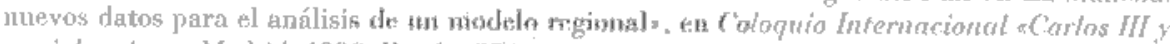
sut siglon. Alitas, Madrid, 1090, IL päy. 834.

14) BARREDA-CARRETERO: 0.c., júgs, 40-49.

13. J. M. CARRLTERO ZAMORA Ibid.

132 BARREDA-CARRETERO: o, c; pág. 54. 
Otro tipo de funcionarios, más asimilable a la mesocracia y, en algún caso, de impronta burguesa, eran los secretarios del Ayuntamiento, los abogados de los Reales Consejos, procuradores de la tierra, los administradores dependientes de la Administración central -de Salinas, de Expolios y Vacantes, de la Renta del Tabaco-, 1 fiscal del Real Juzgado, hermanos del Tribunal de la Hermandad Vieja, 1 secretario de la Inquisición y 1 alguacil honorario de la Inquisición. De las Sociedades de ámbito rural tenemos pocos datos, pero parece que los funcionarios, como el procurador síndico general de los bienes, propios y rentas de Yébenes, eran la excepción en un contexto de alabradores de mediano pasar».

Excepcionales pueden considerarse también los profesionales o «intelectuales» -1 estudiante y 2 licenciados, posiblemente eclesiásticos, en Toledo; 1 notario, 2 escribanos de número y 1 individuo del Colegio Botánico, en Cuenca-, en raros casos, burgueses. Alejados de la burguesía debían de estar también los abogados y escribanos de Vara de Rey, Bogarro y Arbancón.

\section{e) Las Económicas en Levante}

Las recientes monografías de F. Aleixandre ${ }^{139}$ y M. Velázquez ${ }^{134}$ sobre las Sociedades de Valencia y Murcia nos permiten, a reserva de futuros estudios, una satisfactoria aproximación al perfil sociográfico de las Económicas en la órbita levantina, y en concreto, al papel que en ellas desempeñó la burguesía.

Las variables que vamos a manejar son las usadas en casos anteriores: la evolución del número de socios -que expresa, en cierto grado, la importancia y prestigio de la institución-, la cuantía y tipo de burgueses que colaboraron en ellas y el nivel de participación de los mismos en las tareas societarias. Y para ello, utilizamos tres fechas: una correspondiente a la etapa fundacional, otra del momento de la presunta -a veces, inexistente-decadencia y una tercera, de fin de siglo.

133 F. ALEIXANDRE: La Real Sociedad Económica de Amigos det País de Vulencia. Marco juridico, estructura social y financiación (1776-1883). Valencia, 1983.

13. M. VELÁZQUEZ: La Sociedad Económica de Amigos del Pás del Reino de Murcia: In Institución, los hombres y el dinero (1777-1820). Murcia, 1989. 


$\begin{array}{rrr}1775 & 476 & (1777) \\ 1788 & 206 & 197 \\ 1800 & 203 & 250\end{array}$

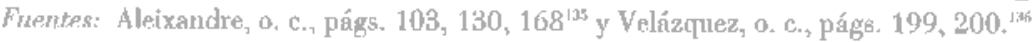

A tenor de los datos resumidos en el cuadro, la evolución del número de socios sigue un ritmo distinto en cada entidad: cn Valencia tiende a decrecer y en Murcia, con la salvedad que hago en la nota 4 , la tendencia es al aumento. El panorama canbia algo si se contemplan las inflexiones de los años 90 , malos para unos y otros.

En las tareas de ambas Sociedades couperaron grupos sociales diversos: la nobleza, el clero, la burguesía, la inesocracia.

Los estamentos privilegiados estuvicron representados en cuantía apreciable.

Ėr Valencia había, er 1778,65 socios nobles -lo que equivale a un cuarto puesto, tras los eclesiásticos, los comerciantes y los miembros de la Administración- y 159 eclesiásticos-grupo predominante en la Socicdad-. ${ }^{137}$ Diez años después, las cifras eran, respectivamente, 25 y 74 ; los nobles, por su múmero, seguían ocupando un cuarto lugar, precedidos por los celesiásticos, los comerciantes y los funcionarios, y los eclesiásticos volvían a ser los más numerosos. $\Lambda$ fines de siglo, la cuantía había disminuido y la proporción había cambiado: 33 nobles -rifra sólo superada por los eclesiásticos y supcrior a la de comerciantes y funcionarios- y 45 clérigos.

El panorama de la Económica Murciana es distinto. Velázquez no ofrece datos anuales, sino una cuantifícación conjunta para los años de 1777 a 1820.

13) I as cifras manejadan por F. ALEIXANDRE divergen; las listas impresas de la Sociedad para 1775 regístran 481 socios (pág. 103) ó 477 (pág. 130), y la corregida, tras la identificación de scxios cuya profesión no se especifica en las listas oficiales, 476 (pág. 168). Fn 1788 figuran en las listas oficiales 216 sucios (pág. 103) ó 206 (130), y en las corregidas, 206. Los daros para 1800 son, respectivumente: 198 (pág. 103), 203 (pág. 130) y 203 (pág. 168).

3: VELÁZQUUEZ registra las inseripciones anuales y la distribución por categorias de los amigos del Pais, pero no se refiere a las posibles bajas que se produjeron cada año. Las sumas, realizadas por mí, pueden contener, pues, algún error.

197 F. AlLEIXANDRE, tabla VI, pág. 168. Los datos no son muy distintos si se usa conto fuente la lista de socios impresa, como se acredita en la tabla IV de AJEIXANDRE, pág. 128. Véanse, adenás, las conclusiones sobre la presenćia de la nobleza en la Sociedad, pág. 172. 
Conforme a ella, sabemos que los nobles fueron, a lo largo de ese tiempo, 35 -es decir un 7,6 \% del total de socios-y los eclesiásticos, 132 -lo que equivale al $28,4 \%$ del total.

La cuantía de los burgueses presentes en las Sociedades levantinas fue muy apreciable, aunque con panoramas distintos en Valencia y Murcia.

La burguesía económica -integrada por comerciantes y fabricantes- alcanzó en Valencia un volumen considerable, mientras que en Murcia sucedió lo contrario. Según las investigaciones de F. Aleixandre ${ }^{138}$ y M. Velázquez, la evolución fue la siguiente:

Cuadro X. Número de comerciantes y fabricantes en Valencia y Murcia

\begin{tabular}{lrc}
\hline Valencia & 1778 & 80 \\
& 1788 & 58 \\
& 1800 & 54 \\
Murcia & $(1777-1820)$ & 9 comerciantes $(2 \%$ del total de socios $)$ \\
& & 7 fabricantes $(1,5 \%$ del total $)$ \\
\hline
\end{tabular}

Fuentes: Aleixandre, o. c., págs. 103, 168, 179; Velázquez, pág. 214.

El marco en que desenvuelven su actividad ambas entidades impone unos lógicos condicionamientos.

En Valencia, cuya trayectoria mercantil es bien conocida, «la presencia y hasta el cierto predominio de la burguesía mercantil durante la primera etapa de vida de La Económica no ofrece lugar a dudas». En 1778 el número de miembros de la burguesía «económica», «si bien es la mitad del de eclesiásticos y algo inferior al de cargos de la administración, se sitúa en un notable tercer puesto, incluso por delante de la nobleza». Diez años después, comerciantes y fabricantes constituyen el segundo grupo en importancia numérica, y esta tendencia al alza se confirma en la época siguiente. De 1796 a 1808 «se mantienen al frente de la Sociedad, si bien acusan los altibajos generales del período ${ }^{139}$ A ellos pueden asimilarse, en cierta medida, los pocos hacendados -3 en 1778,5 en 1788 y 6 en 1800 - que colaboraron con la entidad.

${ }^{138}$ Véase la tabla VI, pág. 168, relativa a la estructura social tras la identificación de socios cuya profesión no se identifica en las listas de socios. El número de comerciantes y fabricantes deducido de las listas de socios impresas -ALELXANDRE, págs. 128-129 era, respectivamente, de 23 (1778), $33(1788)$ y $29(1800)$.

137 F. ALEIXANDRE: o.c., pág. 179. 
En Murcia el grupo de la burguesía «económica» es escaso en número, pero tuvo individualidades de peso. En él cabe situar a «los grandes propietarios no titulados [23 hacendados], notarios fabricantes la mayoría directores de la fábrica de hilar y torcer seda a la piamontesa (salvo un maestro tejedor oriundo de Valencia) - ... y acaudalados comerciantes». ${ }^{1+0}$

Dos grupos que guardan concomitancias con la burguesía, aumque no siempre puedan asimilrse a ella, son los funcionarios y los profesionales. ¿En qué medida estuvieron representados los prinieros?

\section{Cuadro XI. Numero de funcinnarios en Falencia Y Murcia}

\begin{tabular}{lrr}
\hline Valencia & 1778 & 90 \\
& 1788 & 30 \\
& 1800 & 21 \\
Murcia $\quad(1777-1820)$ & 122 \\
\hline
\end{tabular}

Fìentes: Aleixandlue, o. c., págs. 168, 177; Velázquezz, pág. 201.

En Valencia los funcionarios pertenecían a organismos diversos: la Administración central -los más numerosos al principio-, la Audiencia y el Ayuntamiento. Algunos de ellos estarían próximos a la nobleza o podrían calificarse de burgueses, pero otros no superaban el nivel de la mesocracia. En 1778 constituían la segunda fuerza de la Sociedad, tras los eclesiásticos. Dos lustros más tarde habían descendido no poco, y se situaban por detrás de los clérigos y los comerciantes y fabricantes. En el umbral del nuevo siglo estaban por debajo de comerciantes, fabricantes, eclesiásticos y nobles.

La perspectiva de la Económica de Murcia armonizaba más con los ras gos de una estructura social propia del Antiguo Régimen. Velázquez estima en 122 -es decir, un $26,4 \%$ del total de socios- el número de funcionarios asociados a la entidad entre 1777 y 1820 . Ocho de ellos pertenecían a la Administración central, 17 eran agerentes de la Administración provincial», 47 regidores, abogados de los Reales Consejos, 18 corregidores o intendentes y 17 funcionarios mumicipales de otras categorías. ${ }^{1+1} \mathrm{Y}$ estas cifras deben aumentarse si se considera que *todos los altos cargos políticos del momento fueron declarados miembros natos de la Económica». "Numerosos sujetos de la nobleza eran también regidores o desempeñaban profesiones y, a través de ellas, figuraban en las listas de socios.

\footnotetext{
HO) M. VFLÁZQUEZ: o.c., Dág. 214.

141 M. VELÁZQUEZ: 0.c., pág. 201
} 
Las «profesiones liberales» están pobremente representadas en la Sociedad Valenciana. En 1778 contaban con 15 socios, en 1788, 4 y en 1800, 4. Eran catedráticos de Universidad, médicos, un periodista, un cosmógrafo, dos ingenieros hidráulicos y otros sin especificar. ${ }^{142}$ No muy distinto debió de ser el panorama en Murcia. Velázquez ${ }^{143}$ ha identificado 54 profesionales - 0 sea un $11,7 \%$ del total de socios-, pero a lo largo de un amplio período de tiempo -1777 a 1820-, que excede con mucho el siglo XVIII. Por su importancia numérica estaban ordenados así: médicos, catedráticos, administradores, profesores, arquitectos, pintores y botánicos; en las listas figuran, además, 1 escultor, 1 farmacéutico, 1 notario y varios sin especificar.

Si no es exagerado decir que algunos de los personajes incluidos entre los funcionarios o los profesionales pertenecían más bien a la mesocracia, más difícil es ubicar en la burguesía a los pocos miembros del Ejército o la Marina identificados en las Sociedades levantinas. En Valencia, donde la presencia de militares y togados ha sido acertadamente analizada por P. Molas, ${ }^{144}$ había 23 militares en 1778, pero luego bajaron a 1, en 1788, y 8, en 1800 . Sólo avanzado el s. XIX se registró un notable aumento.

En Murcia los militares alistados, entre 1777 y 1820 , fueron 31 -es decir, el $6,7 \%$ del total de socios-. Eran, «mayoritariamente, jefes y oficiales del regimiento provincial de milicias, algunos de ellos ya retirados, así como unos pocos miembros de la armada, también de alta graduación -capitanes de fragata, capitanes de navío y fiscal militar y otros».

Siguiendo la ruta andada por otros investigadores, y con el propósito de afinar el análisis, F. Aleixandre y M. Velázquez se han preguntado por el grado de compromiso y participación de los socios de impronta burguesa o filoburguesa en las Sociedades levantinas.

En líneas generales, Aleixandre ha discernido, a través del número de veces que se reúnen las Juntas, cuatro períodos en la actividad de la Valenciana. Tras una fase de regularidad inicial, entre 1778 y 1785 , con un número de juntas que oscila entre 37 en el primero de los años citados y 26 en el último, hay un fugaz intento de recuperación, de 1786 a 1789 , en cuyos años el número de juntas es superior a 40 -salvo en 1787 - y un descenso de

142 F. ALEIXANDRE: o.c., págs. 128,129 y 168.

14 M. VELÁZQLEZ: o.c., págs. 201 y 213

14 P. MOLAS: ailitares y togados en la Valencia borbónicá, en Actes du I Colloque sur le Pays Valencien à l'époque moderne, Pau, 1980, págs. 171-187. 
actividad en los 90 -excepción hecha de 1792,1795 y 1799 - A comienzos de siglo se registra una clara reacción.

¿Cuántos socios asisten a las juntas, con qué intensidad intervienen? Para dar respuesta a estas difíciles preguntas $\mathrm{F}$. Aleixandre se sirve de datos numéricos:

Cuadro XII. Asistencias de socios en Valencia

\begin{tabular}{ccc}
\hline Años & $\begin{array}{c}\text { Número de sucios que } \\
\text { asisten alguna vez }\end{array}$ & $\begin{array}{c}\text { Número de socios que asisten al } 40 \% \\
\text { de las Juntas }\end{array}$ \\
\hline 1785 & 56 & 11 \\
1788 & 53 & $9(5 \%$ del total de socios $)$ \\
1794 & 20 & $5(3,3 \%$ del total de socios $)$ \\
1800 & 44 & $8(4,6 \%$ del total de socios $)$ \\
\hline
\end{tabular}

Fuente: If. Aleixandre, o, c., pág. 194.

Las cifras son expresivas, pero no nos permiten deducir, ni la aportación de cada persona en concreto, ni la presencia en las tareas societarias de los grupos sociales, y en concreto, de burgueses y filobuxgueses.

Aúm contando con las deficiencias que impone la documentación, F. Aleixandre aporta sugestivas informaciones. Dejando de lado el tema de la asistencia de cada socio a las Juntas, trabajosa y útil reconstruceión realizada por la autora, nuestra atención debe fijarse en la conformación del grupo dirigente y la presencia en él de la burguesía. Según F. Aleixandre, la minoría rectora, entre 1778 y 1785 , estuvo compuesta por «nueve nobles, cuatro miembros del alto clero, uno del ejército, un hacendado, seis cargos de la Administración y un socio no identificado». Ninguno de los representantes de la burguesía mercantil se introdujo en la Comisión de Estatutos. En cambio, Joaquín Manuel Fox se incorporó a la "Junta Particular, encargada de la selección de nuevos socios". "Quizá quepa atribuirle la integración de un nutridísimo grupo de comerciantes en esta primera etapa, si bien no alcanzan los órganos directivos y se limitan a intervenir en las Comisiones que les afectan o a proponer las empresas que les convienen». ${ }^{145}$

El horizonte social de la entidad era distinto en el periodo de 1785 a 1800 . en esos años, la a minoría dirigente estaba compuesta por seis nobles, seis miembros del estamento eclesiástico, 3 cargos de la Administración, 2 altos cargos

14: F. ALEIXANDRE: o,e, págs. $128,129,168,176$. 
militares, un importante hacendado y 4 socios de lo que hoy llamaríamos profesiones liberales (abogados, médico y agrónomo), frente a 13 miembros de la burguesía mercantil valenciana, que han aprovechado el último tercio del siglo XVIII para afirmar su posición social, conquistar su título de hidalguía, etc. y ejercen el control de la Sociedad... No es casual que durante estos años la Económica se ponga al frente de una serie de empresas (las repetidas de la Junta de Convoyes, expediciones a América, etc.) que afectan claramente a los intereses de la burguesía valenciana de la época». ${ }^{140}$

Matías Velázquez afronta la cuestión respecto a Murcia desde una perspectiva análoga.

Si la aportación del clero y, en menor medida, la nobleza fue importante para la entidad, influyó más en ella el grupo de los funcionarios. El hecho no extraña porque los miembros de la Administración seguían así las directrices del poder y buscaban la oportunidad «de obtener puestos de mayor responsabilidad política ${ }^{147}$ Pero la respuesta de los funcionarios no fue la misma en todos los casos. Los socios honorarios, miembros de la Administración central, asistieron poco a las juntas, pero los socios honorarios pusieron al servicio del instituto su prestigio e influencias. Las autoridades -como el corregidor y el justicia mayor de Murcia-, los delegados locales o provinciales de la Administración central -administradores de Rentas, contador de la Real Fábrica de Salitres y Pólvora de Murcia, comisario ordenador del Ejército y otros- u oficiales de ciertos departamentos, tomaron, en cambio, parte muy activa en el gobierno y actividades de la Sociedad. Lo mismo sucede con los abogados de los Reales Consejos. Pero la «columna vertebral» de la institución eran los regidores, muchos de ellos terratenientes interesados por cuanto la Económica hiciera respecto al campo y aspirantes a ser interlocutores preferentes ante la Administración central. Presencia activa tuvieron tambiér otros integrantes del equipo municipal, como dos procuradores síndicos, un diputado del común, dos alcaldes mayores, jurados, un secretario del Ayuntamiento y un tesorero de Propios y Arbitrios.

En cuanto a los militares alistados en la Sociedad, no participaron en ella muy activamente.

Mayor dinamismo e interés mostraron los profesionales. Su nivel de participación fue alto «debido a la formalidad que caracteriza a los componentes de este heterogéneo grupo». ${ }^{1+\beta}$ Particularmente activos fueron algunos miembros

\footnotetext{
14 F. ALELXANDRE: o.c., págs. 222-223.

1.7 F. ALEIXANDRE: o.c., págs. 228-229.

Ho M. VELÁZZQUEZ: o.c., pág. 210.
} 
del Seminario de San Fulgencio, del colegio de Teólogos de San Isidro, de la Academia de Medicina o altos cargos de la fábrica de salitres.

¿Y qué decir de los hacendados, fabricantes y comerciantes, es decir, de la «burguesía económica»? En cuanto a los primeros, brillaron, salvo excejeciones, por su ausencia, en parte, porque vivían fuera de Murcia, en parte, porque no se sintiem motivados. I on fahricantes -e incluso los directores de la fábrica de hilar y torcer seda a la piamontesa- y comerciantes, según M. Velázquez, «además de ser un grupo marginal cuantitativamente, también lo es desde el punto de vista cualitativo a tenor del escaso empeño que manifestaron en las tareas de la entidad". ${ }^{\text {to }}$

\section{f) Andalucía}

No son muchos los estudios dedicados a las Sociedades Económicas andaluzas en los últimns años. ${ }^{150}$ Alguno de calidad, como el de Juan Luis Castellano, ${ }^{151}$ dedica más atención a otras cuestiones que a las que nos ocupan. Trabajos de síntesis, como los de Aguilar Piñal ${ }^{152}$ o Gay Armenteros y Viñes Millet, ${ }^{159}$ no se proponen rastrear la huella de la burguesía en los beneméritos institutos. Una orientación distinta tienen también los trabajos, de intención monográfica, de G. y P. Demerson ${ }^{154}$-sobre la sociedad de Vélez Málaga-, Gareía García ${ }^{15}$ -que se ocupa de la Sociedad de Cabra-, Abras -de la de Lucena-, ${ }^{1,60}$ Enciso ${ }^{157}$

146 M. VELÁZQUEZ: o.c., pág. 213.

15. Para una aproximación bibliográfica debe acudirse a F. AGUILAR, Bibliografía de estudios sobre Carlos II y su época, Madrid, 1988, págs. 125, 126, 127, 128, 129, 130, 131.

15. J. L. CASTELLANO: Luces y reformismo. Lets Sociedudes Eronómicas de Amigos del Paús det Reino de Granada en el s. XHII, Gramada, 1984.

15: F. AGUILAR PINALL: aLas instituciones culturales. IV. Sociedades Económicas y Ateneos", en Historic de Andalucía, Madrid, 1981, 1. V, pags. 341-356; del mismo, Historia de Sevilla, Sevilla, 1982.

173 J. GAY ARMLN'ILROS-C: VINLS MILLET: «Las Reales Sociendades Econonnicas de Amigos del País*, en Lr Ihstrorión andaluza, Baxcelona, 1985, págs. 119-147.

1.t C. y P. DEMERSON: aJa Sociedad Econúmica y patrińtica de Vélez Málaga. Notas para

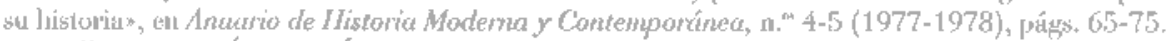

19. J. GARCÍA GARCÍA: «Real Soriedad Económica de Amigos del País de Cabra (Córdoba)*, Actas del I Congreso de Historir de Andalucía. Andalucía Moderna. Siglo XWH, Gordoba, 1978 , Ł. 1, págs. 221-227.

15. J. A. ABRAS SANTIAGO: «La Real Sociedad Laboriosa de la M. N. y M. L. Ciudad de Lucena (1782), en Actas del I Congreso de Historiu de Andalucin. Andalucía Moderna. Siglo XVII, Cúrduba, 1978, t. I, págł. 3-12.

1:7 L. M. ENCISO REGIO: „La Sociedad Económica de Jerez de la Frontera a finales del reinado de Carlos III» en Ceademos de Thuestigación Fistónica, n, $3(1979)$, págs, 367-386. 
-relativo a la de Jerez de la Frontera- y Cosano ${ }^{158}$-centrado en la Económica Cordobesa.

Más afines al propósito de este trabajo son las obras que Arias de Saavedra ${ }^{159}$ dedica a las Sociedades Económicas de Amigos del País del reino de Jaén, precedida por otra, más breve, de F. Sánchez Salazar sobre la Económica jiennense $^{160}$ y A. López Martínez a la Sociedad de Málaga. ${ }^{161}$

Inmaculada Arias se ha servido del «Catálogo de sujetos que se han convenido a formar la Junta de Verdaderos Patricios» para analizar la composición social de la anticipadora Sociedad de Baeza. De los 21 miembros del «Catálogo», se desconoce la filiación de 9. Entre los restantes, predomina el estamento eclesiástico - con cinco personas- seguido de cuatro militares -tres oficiales de Milicias y un alférez de Dragones del Rey- y tres nobles titulados. Para completar sus hipótesis interpretativas, Arias de Saavedra utiliza los Estatutos, en los que se muestra «una predisposición clara a ser una Sociedad que recibe en su seno a los estamentos sociales superiores, es decir, a la nobleza y al clero, y singularmente, a la nobleza». Poca huella burguesa podía encontrarse, pues, en la entidad.

Distinto es el panorama que se ofrece en la Sociedad de Jaén. La lista de socios permitió a F. Sánchez de Salazar ofrecer un cuadro sobre la extracción de los 96 miembros de la Sociedad, rectificado y ampliado por Inmaculada Arias.

El número de nobles -6, según Sánchez de Salazar, 9 (un $9 \%$ del total de socios), en opinión de I. Arias- no fue crecido en términos absolutos, pero sí en relación con los demás miembros. Sánchez de Salazar ${ }^{162}$ interpreta que el papel de la nobleza fue poco relevante, pero I. Arias opina que la "proporción era importante para una ciudad como Jaén donde la nobleza no era paticularmente numerosas. ${ }^{163}$ El papel del clero es subrayado por las dos investigadoras.

15. J. COSANO MOYANO: «La Real Sociedad Económica Cordobesa de Amigos del País», en Córdoba, apuntes para su historia, Córdoba, 1981, págs. 171-194.

15. I. ARIAS DE SAAVEDRA: Las Sociedades Económicas de Amigos del País del Reino de Jaén, Granada, 1987. En ella se resumen artículos anteriores sobre las Sociedades de Baeza y Quesada.

100 F. SÁNCHEZ SALAZAR: La Real Sociedad Económica de Amigos del Pais de Jaén (1786-1861), Jaén, 1983.

161 A. LÓPEZ MARTínEZ: La Sociedad Económica de Amigos del País de Málaga, Málaga, 1987.

16? F. SÁNCHEZ DE SALAZAR: La Real Sociedad de Amigos del País de Jaén, pág. 115.

16 I. ARIAS, Las Sociedades Económicas de Amigos del País del Reino de Jaén, pág. 206. 
Sánchez de Salazar ha identificado a 54 socios eclesiásticos e I. Arias a 55 -un $56 \%$ del total-, y ambas entienden que el clero fue el grupo más importante.

Otro grupo social bien definido y numeroso dentro de la Económica jiennense era el de los militares -9 , según Sámchez de Salazar, 10 (un 10 \% del total), en opinión de I. Arias-. La mayor parte eran «altos cargos del regimiento de milicias de la provincian, a los que acompañaban militares destinados a otros lugares y ligados a Jaén, probablemente, por lazos familiares: un teniente coronel del Ejército y teniente del real cuerpo de Guardias españolas, un teniente del regimiento de infantería de Vitoria, un teniente coronel del Ejército y capitán de fragata y un teniente de Dragones de Almansa. No conocemos bien su ascendencia social,

Tampoco es desdeñable el peso de los 19 funcionarios -más del $15 \%$ del total de socios-. Figuran en la lista el intendente, el corregidor de la ciudad de Jaén y el de Alcalá la Real, cuatro caballeros veinticuatro de Jaén y varios delegados de la Administración de Hacienda -contador principal y secretario de la superintendencia, de Propios y Arbitrios de la provincia, administrador de la Renta de Tabaco, administrador y tesorero de las Rentas provinciales y generales- y un alcalde del crimen.

Si se execptúan algunos de cstos individuos de las élites locales o provinciales, la huella de la burguesía en Jaén fue escasa.

Muy otro es el horizonte que presenta la Sociedad de Málaga. El librito de A. López Martíncz, pese a lo sumario de sus informaciones, basta para convencernos ${ }^{164}$ del importante papel jugado en la Sociedad Económica malagueña por la burguesía mercantil, los funcionarios dependientes de la Administración central o local y los profesionales.

Sin embargo, en su etapa fundacional, la entidad respiraba todavía aíres propios del Antiguo Régimen. la solicitud al Rey para la creación de la Sociedad -19 de noviembre de 1788- estaba firmada por seis promotores de los cuales dos eran nobles, otros dos funcionarios y dos clérigos y 46 solicitantes más. Entre estos últimos, había 5 títulos, 5 dignidades de la Iglesia, 6 canónigos, 5 prebendados, 6 regidores y 19 «particulares» de los cuales, 3 niembros de la nobleza media, 2 eclesiásticos, 5 militares, 4 funcionarios y 5 no identificados. ${ }^{165}$

*i* ASUNCIÓN LÓPEZ MARTÍNEZ: La Sociedad Económica de Amigus del Pais de Málaga, Málaga, 1987.

${ }^{163}$ A. LÓPEZ MARTínEZ: La Sociedad Económicat. de Málega, págs, 74-75. 
A tono con ello, la primera Junta directiva la integraron el obispo de la diócesis, un noble, dos eclesiásticos más y dos funcionarios. ${ }^{160}$

Tiempo después, el 12 de octubre de 1790, aprobados los Estatutos, se celebró el sorteo de los socios fundadores. Estaban presentes 104 personas, pero tres de ellas -el conde de Floridablanca, el de Campomanes y el marqués de Valle Hermoso- tenían la calidad de socios honoríficos.

De los 101 socios activos, 11 eran nobles, 38 eclesiásticos y 14 militares -la mayor parte del colectivo militar, además, pertenecía a la nobleza y tres individuos hacían compatible su condición nobiliaria con la de funcionarios y miembros del clero castrense- y 38 burgueses.

Apurando un poco el análisis de este último sector, encontramos en él 18 personas vinculadas al «alto comercio marítimo», 16 funcionarios -7 delegados en Málaga de la Administración central, 3 regidores o síndicos personeros, 1 alcalde mayor, 1 alcalde del crimen de la Chancillería de Valladolid, 1 cónsul de Polonia, 2 diputados del partido de Málaga, 1 director del Colegio de San Telmo de Málaga- y 4 profesionales -abogados todos-.

Este primer apunte sociográfico puede completarse con otras observaciones de A. López Martínez. Aunque, en rigor, no ofrece una panorámica de la vida societaria y de la presencia en ella de los diversos socios, deja entrever algunas facetas al referirse a los «estamentos sociales activos en la Sociedad». Con razón afirma que, entre los componentes de la entidad, "los que predominaban eran los socios dedicados al comercio, industria y otras actividades». Y, para demostrarlo, acude a la lista de asociados nombrados para las comisiones de agricultura, comercio y arte.

La nómina de los que mostraron interés por las actividades agrícolas -26-, descontados los no identificados, revelan un predominio de funcionarios $-9-$, acompañados en la tarea por nobles -5-, militares -3- y eclesiásticos -1-.

La rama del comercio atrajo a una cantidad ligeramente menor de socios -21-, y salvo 6 no identificados, los demás pertenecían al «alto comercio» -10y al pequeño comercio de la ciudad -3-, a más de 1 noble y 1 diplomático.

A la comisión de arte se dedicaron, aparte 17 no identificados, 20 eclesiásticos, 7 funcionarios, 6 militares, 3 profesionales y 2 nobles.

Hubiéramos deseado ver en acción a todos y a cada uno de lós socios, y

twe A. LÓPEZ MARTÍNEZ: La Saciedad Económica... de Málaga, págs. 76-77. 
comprobar quiénes se esforzaron día a día, quiénes lo hicieron a ráfagas y quiénes se limitaror a inscribir su nombre en las listas y poco más. Pero si, a través de la medición de asistencias y ausencias de individuos y sectores sociales o de otros procedimientos, no podemos, hoy por hoy, alcanzar el objetivo apuntado, todo induce a pensar que las conclusiones de A. López Martínez no van descaminadas. En la Sociedad de Málaga no es desdeñable el trałajo de «unos pocos anistócratids ilustrados, yue culaburan con entusiasno, urgullosus... de contribuir a una mejora agrícola, industrial o cultural de la zona, incluyendo, naturalmente, sus mismas propiedades s. Fue también plausible el esfuerzo de «prelados, canónigos» y otros sectores del clero y de «personas de cultura y carrera, profesionales liberales, intelectuales». Sin embargo, los «socios más activos y dispuestos» debieron de ser miembros de la burguesía mercantil, «bien situados económicamente», que participaron en ala obra común, tanto por motivos de mentalidad e ideas como por la defensa de sus propios intereses».

\section{g) Canarias}

No son muy explícitos, salvo excepciones, los análisis sociográficos relativos a las Sociedades Económicas canarias.

El signo erudito del trabajo de E. Romeu Palazuelos sobre la Económica de Tenerife ${ }^{167}$ lo hace poco útil para nuestro objeto. Tampoco Manuel de Paz proporciona pistas para conocer la composición social de los Amigos del País de La Palma. ${ }^{160}$ Gracias a él sabemos, sin embargo, que a la reunión fundacional, promovida por el obispo de Canarias, Juan Bautista Cervera, el 29 de agosto de 1776 , acudieron treinta y tres personas, entre los que había «nobles, más o menos segundones, y caballeros, propietarios y comerciantes, militares, burócratas y miembros del clero». En concreto, uno, a más de capitán del regimiento de milicias, era señor de Lilot; otro, teniente y castellano; dos más, capitanes del regimiento de milicias y miembros de Ordenes Militares; cinco combinaban la condición militar -capitanes del regimiento de milicias, y subteniente de milicias y teniente capitán, respectivamente-con otros cargos - uno, regidor decano, dos regidores, un cuarto alférez mayor y el quinto, familiar de la Inquisición-, y ocho eran sólo militares -un coronel y gobernador de las armas, cinco capitanes del regimiento de milicias, un ayudante mayor de milicias y un teniente capitán-. A ellos se añadían seis eclesiásticos-dos prebendados, dos

107 E. ROMEU PALAZUELOS: La Económica a trnués de sus actas. Años 1776 a 1800, La Laguna, 1970.

16* M. DE PAZ SÁNCHEZ: Los Amigos del Pais de La Palma. Siglos XVHY XX, Santa Cruz de La Palma, 1981, págs. 15-16. 
beneficiados (uno comisario y otro notario de la Inquisición) y dos presbíteros-, cinco funcionarios o cargos administrativos - un licenciado y alcalde mayor, un juez subdelegado del comercio de Indias, un administrador de la Real Aduana, un síndico personero y un licenciado y sustituto fiscal-, un comerciante-que, además, era regidor-y un profesional-médico-, No hace falta decir que la huella burguesa es tenue.

La primera aproximación, todavía tímida e insuficiente, a la fisonomía social de una de las Económicas canarias es la dedicada por Cristóbal García del Rosario a la Real Sociedad de Amigos del País de Las palmas de Gran Canaria. ${ }^{160}$

García del Rosario distingue tres periodos en la evolución de la Sociedad hasta 1900: 1777-1808, 1809-1860 y 1861-1900. De ellos, sólo los dos primeros atraerán nuestra atención.

La composición social de la primera etapa ha sido resumida así por García del Rosario: ${ }^{170}$

Cuadro XIII. Composición social de la Económica de Las Palmas

\begin{tabular}{lcc}
\hline & Número de socios & Porcentaje \\
\hline Clérigos & 94 & $42,8 \%$ \\
Militares & 53 & $26,8 \%$ \\
Funcionarios y profesionales & 24 & $10,9 \%$ \\
Nobles & 13 & $5,9 \%$ \\
Propietarios y comerciantes & 2 & $0,9 \%$ \\
Sin especificar & 28 & $12,7 \%$ \\
\hline
\end{tabular}

Fuente: C. García del Rosario, La Real Sociedad de Las Palmas, pág. 28.

Aunque no se matiza la condición de los individuos que componen cada grupo, podemos arriesgar algunas conclusiones.

En primer lugar, hay que subrayar el predominio de clérigos -obispos, dignidades eclesiásticas, párrocos y otros, algunos de tanta notoriedad como Viera y Clavijo- y militares, hecho que se repite en todas las Sociedades canarias. En ellas se refleja bien la imagen de un contexto social antiguo, en el que el dirigismo oficial sigue considerándose palanca prioritaria de transformación, inspirada en el modelo de la Matritense sea en el ámbito urbano, como Las Palmas, o en el ámbito rural, como La Palma o La Gomera.

169 C. GARCÍA DEL ROSARIO: La Real Sociedad Económica de Amigos del País de Las Palmas de Gran Canaria, Las Palmas, 1982.

no C. GARCIA DEL ROSARIO: c.o., pág. 28. 
Al igual tyue en otras Socicdades programadas descle el poder ${ }^{\text {br }}$ en Las Palmas-entidad modélica para las demás de las Islas- ${ }^{121}$ abunda la presencia de autoridades y, por decirlo con cierta simplificación. funcionarios. Ellos y los profesionales -cuya cuantía no conocemos, y entre los que cabe recordar al arquilecto Diego Nicolás, o al periodista José Clavijo y Fajardo-desempeñaron un papel te cierta importancia entre los Amiges grancanarios. Asimismo se inscribió en la Sociedad, aunque ignoramos sn nivel de participacion, un apreciable número de nobles.

Pese a que la Eeomónica de Las Palmas estaba ubicada en un medio urbano, los socios burgueses, o asimilables a la burguesía, fueron pocos. Si dejamos de lado algunos funcionarios o profesionales, el balance numérico de cstc sector no supera el $1 \%$ del total de miemibros.

Todo to contrario suctio entre 1808 y 1860 , en cnya ctapa la semilla liberal, destinada a arraigar con especial fuera en las Islas Afortunadas, cohró fuerza. Pocos argumentos podrán ser tan elocuentes como las estadísticas comparadas de socios aportadas por García del Rosario: 173

\begin{tabular}{lcc}
\hline & Etapa 1777-1808 & Etapa 1809-1860 \\
\hline $\begin{array}{l}\text { Clérigos, militares y nobles } \\
\text { Funcionarios, profesionales, propietarios, } \\
\text { comerciantes y sin espccificar }\end{array}$ & 75,4 & $28,6 \%$ \\
\hline
\end{tabular}

Aún contando con la parquedad de fuentes utilizables, el perfil sociográfico más ajustado de Sociedades Canarias lo ha ofrecido Juan Carretero en su estudio sobre la Económica de La Gomera. ${ }^{174}$

La personalidad de los miembros de la primera junta directiva es asimilable, desde la perspectiva sociográfica, a lo que luego va a repetirse en la lista de fundadores: la primacía de clérigos y militares. «De los 63 miembros fundadores de la Sociedad», explica Carretero, "21 pertenecen al estamento militar $(31,3 \%)$-un abanderado, dos ayudantes mayores de infantería, site capitanes, $1 \mathrm{~m}$ comandante, cuatro subtenientes y seis tenientes-, 19 eran clérigos $(28,4 \%)$

171 J. CARRETERO ZAMORA: *TTopía y realidad de un proyecto ilustrado: la Sociedad Ecomómica de Aunigus del País de La Gomeran, en Espacio Tternpo y Forma, serie IV, H. Modena, t. JV (1991), pág. 204.

172 J. CARRETERO: Ibid,
17: C. GARCIA DEI, ROSARIO: $0 . c$, pás. 30.
174. GARRETERO ZAMORA: art. cit., págs. 211-215. 
-1 obispo, un vicario, cinco párrocos, dos beneficiados y diez presbíteros-, 14 estaban incluidos en cargos y oficios de la administración local y territorial $(20,9 \%)$-seis alcaldes, un alcalde mayor, un alguacil mayor, un personero general y cinco regidores- y 13 eran presentados como "vecinos».

Con razón afirma Carretero que «la composición social de la Económica de La Gomera no difería del resto de Sociedades rurales y semiurbanas. La masiva incorporación del estamento militar -en toda su jerarquía, desde comandante hasta subteniente-», apunta, «constituía un fenómeno típico en este tipo de instituciones; los militares bajos y medios se adscribieron a la Sociedad arrastrados de manera colectiva siguiendo el ejemplo de sus superiores jerárquicos. Es seguro que, de haber existido un núcleo apreciable de funcionarios, el mecanismo mimético se hubiera reproducido en análogo sentido». ${ }^{776}$ Una explicación semejante puede darse, en opinión de Carretero, a la presencia del clero, algunos de cuyos componentes eran proclives, como se hace ver en la bibliografía reciente, al fenómeno ilustrado y a las Sociedades, ${ }^{177}$ proclividad acentuada, en el caso de La Gomera, por las exhortaciones del obispo Carrera.

El entusiasmo hacia las Sociedades de buena parte de los cargos y oficios de la Administración ha quedado acreditado en varias de las páginas del presente trabajo. Con no poca perspicacia, ha hecho notar Antonio Miguel Bernal el importante papel que jugaron, en Canarias, durante el tránsito del antiguo al nuevo régimen, en concreto en las Sociedades Económicas, «las burguesías locales insertas en el aparato de la política municipal». ${ }^{178}$ Carretero, por su parte, asocia a las autoridades locales y a los propietarios -necesitados de más tierra de cultivo y menos trabajos jurídicus y físicos- en el propósito de «rclanzar una política reformista agraria», defendida teóricamente por las Económicas y apoyada por el poder local. ${ }^{179}$

\section{Conclusiones}

El debate sobre la burguesía española en la Edad Moderna no parece tener fin. Las discusiones sobre el concepto de burguesía, tejido en las contraposiciones metodológicas, no convoca sólo a los historiadores, sino a sociólogos, eco-

173 J. CARRETERO: art. cit., pág. 212.

176 J. CARRETERO: Ibid.

177 J. CARRETERO: art. cit., págs. 212-213.

${ }_{178}$ A. M. BERNAL: «En torno al hecho diferencial canarios, en Canarias ante el cambio, Santa Cruz de Tenerife, 1981, págs. 25-37.

179 J. CARRETERO: art. cit, pág. 213. 
nomistas, politólogos y antropólogos. Y tanto como una definición de la burguesía en la Edad Moderna, siempre difícil, importa la caracterización de los prototipos burgueses, sus actividades, su variopinto status material, su mentalidad, sus afinidades sociales, políticas o intelectuales. En realidad, a los historiadores de oficio, en los últimos tiempos, nos ha jreocupado, sobre todo, seguir la huella, a veces neblinosa, de los prototipos burgueses y su encaje en las áreas locales o regionales de actuación. No menos atractivo tiene, en la bibliografia actual, el estudio de las individualidades, las familias o las clientelas burguesas. Todas y cada una de las perspectivas de análisis a que me he referido aparecen compendiadas, de una forma u otra, en las Actas, a punto de publicarse, del Congreso sobre La burguesía española en La Edad Moderna, organizado, en su día, por el Departamento de Historia Moderna de la Universidad Complutense y la Fundación Duques de Soria.

No parece dejar lugar a dudas la presencia y la actividad de burgueses en las Sociedades Económicas durante los siglos XVIII y XIX. Los últimos estudios lo acreditan sobradamente. Pero quedan aún muchas zonas de duda o penumbra para trazar um balance de resultados.

La historia social de la Administración no nos ha brindado todavía criterios clarificadores para distinguir los rasgos burgueses o nobiliarios de muchos funcionarios. Y tampoco es fácil situar en su chgranaje social a cada uno de los profesionales, tanto Ios que tenían una órbita privada de acción como los que ofrecían stis servicios al Fstado. Ia misma burguesía aconómicay, tantas veces polivalente y, en muchos casos, contaminada de sespíritu hidalgo», requiere no pocas reflexiones y análisis parciales.

Comcrciantes industriales o fabricantes, propietarios agrícolas, funcionarios y profesionales forman parte, en cuantía y proporción estimable, de los Amigos del País. Pero no siempre y en todas partes.

La revisión bilbliugráfica que hemos realizado permite comprobar que la presencia burguesa es más intensa en Madrid, Levante -sobre todo, Valenciao Málaga, pero también se aprecia, con distintos matices e intensidad, en Aragón, el espacio castellano-leonés y hasta Canarias, aunque, en este último caso, con escasa fuerza. El signo burgués de la Vascongada, la Económica de Mallorca y otras entidades, entrevisto en varios trabajos, exige todavía estudios más convincentes y explícitos.

En todo caso, es seguro que la panorámica que hoy puede ofrecerse, sobre la actuación de los burgueses en las Económicus se AMPLARA y COBRARÁ nuevos vuelos en el futuro gracias a la labor de los investigadores. 